\title{
18. GEOCHEMISTRY AND PETROGRAPHY OF CRETACEOUS SILLS AND LAVA FLOWS, SITES 800 AND $802^{1}$
}

\author{
P. A. Floyd ${ }^{2}$ J. A. Winchester, ${ }^{2}$ and Paterno R. Castillo ${ }^{3}$
}

\begin{abstract}
On the basis of their respective eruptive environments and chemical characteristics, alkalic dolerite sills from the northern Pigafetta Basin (Site 800) and tholeiitic pillow lavas from the Mariana Basin (Site 802) sampled during Ocean Drilling Program Leg 129 are considered to represent examples of the widespread mid-Cretaceous volcanic event in the western Pacific. Both groups of basic rocks feature mild, low-grade, anoxic smectite-celadonite-carbonate-pyrite alteration; late-stage oxidation is very limited in extent, with the exception of the uppermost sill unit at Site 800. The aphyric and nonvesicular Site 800 alkalic dolerite sills are all well-evolved mineralogically and chemically, being mainly of hawaiite composition, and are similar to ocean island basalts. They are characterized by high contents of incompatible elements (for example, $300-400 \mathrm{ppm} \mathrm{Zr}$ ), well-fractionated rare earth element patterns $\left([\mathrm{La} / \mathrm{Yb}]_{\mathrm{N}} 18-21\right)$ and HIMU isotopic characters. They probably represent deep-sea, lateral, intrusive off-shoots from nearby seamounts of similar age. The olivine-plagioclase \pm clinopyroxene phyric tholeiitic pillow lavas and thin flows of Site 802 are nonvesicular and quench-textured throughout. Relative to normal-type mid-ocean ridge basalt, they are enriched in large-ion-lithophile elements, exhibit flat (unfractionated) rare earth element patterns and have distinctive (lower) $\mathrm{Zr} / \mathrm{Nb}, \mathrm{Zr} / \mathrm{Ta}$, $\mathrm{La} / \mathrm{Ta}$, and $\mathrm{Hf} / \mathrm{Th}$ ratios. Overall they are compositionally and isotopically similar to the mid-Cretaceous tholeiites of the Nauru basin and the Ontong-Java and Manihiki plateaus. The Site 802 tholeiites differ from the thickened crustal segments of the oceanic plateaus, however, in apparently representing only a thin veneer over the local basement in an off-axis environment.
\end{abstract}

\section{INTRODUCTION}

One of the major problems encountered by previous attempts to sample Jurassic ocean crust in the western Pacific Ocean were the products of extensive mid-Cretaceous volcanism that filled many ocean basins with seamount-derived volcaniclastic debris and proved difficult to penetrate completely (Lancelot, Larson, et al., 1990). Of the three sites drilled during Ocean Drilling Program (ODP) Leg 129 (Fig. 1), only Site 801 penetrated Jurassic ocean crust; although both Sites 800 and 802 drilled acoustic "basement," these proved to be Cretaceous in age. The clear extrusive nature of the Cretaceous-aged pillow basalts at Site 802 was intriguing, especially as the magnetic anomaly patterns and water depth indicated that the ocean crust in this part of the western Pacific Ocean should be of Jurassic age (Lancelot, Larson, et al., 1990). Was this really Cretaceous ocean crust or another expression of mid-Cretaceous volcanism which spread a thin veneer of extrusives over Jurassic crust lying immediately below? Currently, we prefer the latter tectonic situation. There is little doubt that the mid-Cretaceous volcanic event was a major feature of the central-western Pacific (Larson, 1991) and is represented by different volcanic forms, such as reef-capped seamounts and ocean islands (with their attendent slumped volcaniclastic aprons), enormous oceanic plateaus, such as the Ontong-Java Plateau, and deep-sea sill-flow complexes, as in the Nauru Basin (for example, Winterer, 1973; Schlanger et al., 1981; Larson and Schlanger, 1981; Haggerty et al., 1982; Rea and Vallier, 1983; Schlanger and Moberly, 1986; Floyd, 1989). Leg 129 also demonstrated the existence of other deep-sea expressions of the mid-Cretaceous event in the form of sills intruding Early Cretaceous sediments (Site 800) and pre-Aptian lava flows (Site 802). This paper describes the petrography and geochemistry of these Cretaceous volcanics and briefly discusses their origin and tectonic setting. Isotopic and radiometric age data are discussed in companion papers by Castillo et al. (this volume) and Pringle (this volume), respectively.

\footnotetext{
'Larson, R. L., Lancelot, Y., et al., 1992. Proc. ODP, Sci. Results, 129: College Station, TX (Ocean Drilling Program).

${ }^{2}$ Department of Geology, University of Keele, Staffordshire, ST5 5BG, United Kingdom

${ }^{3}$ Scripps Institution of Oceanography, La Jolla, CA, 92093-0220, U.S.A.
}

\section{LITHOSTRATIGRAPHY AND PETROGRAPHY}

The recovery of igneous rocks from Sites 800 and 802 was limited, with only $7 \mathrm{~m}$ of dolerites (from $58 \mathrm{~m}$ penetration) from the former and $16.6 \mathrm{~m}$ of basalts (from $51 \mathrm{~m}$ penetration) from the latter. Although a number of volcanic cooling units were identified at each site (Lancelot, Larson, et al., 1990), in both cases the rocks sampled show little major lithological and chemical downhole variation, unlike the longer Jurassic crustal sequence at Site 801 (Floyd and Castillo, this volume). However, each location is distinctive in that Site 800 acoustic "basement" is composed of alkalic dolerite sills, whereas Site 802 exhibits tholeiitic basalt lavas. Various petrographic features displayed by the dolerites and basalts from these sites are shown in Figure 2.

\section{Site 800 Alkalic Dolerite Sills}

\section{Mode of Emplacement and Age}

Although actual contacts were not recovered, it is inferred that the three cooling units recognized at this site probably represent intrusive sills rather than lava flows (Lancelot, Larson, et al., 1990). However, interpretation of the emplacement mode of thick, massive, relatively coarse-grained cooling units only seen in incompletely cored sections can often be equivocal, such that intrusives can be confused with thick flows and visa versa. Nevertheless, in areas of rapid sedimentation, where magmas may only occasionally reach the seafloor as lava flows, sill-like intrusives are relatively common. For example, in the Guaymas Basin (Gulf of California) numerous intrusive bodies were emplaced into, and clearly hydrothermally altered, poorly consolidated claystones (Einsale et al., 1980). However, massive bodies of similar thickness and textural variety sampled at the mouth of the Gulf of California were all interpreted as flows rather than sills on various criteria, including absence of intrusive relationships (Griffin et al., 1983). Because of the lack of observable contacts in Hole 800A, the intrusive nature of the three dolerite units was inferred from the following features: (1) basal and interbedded cherty and radiolarite sediments were baked, bleached, and brecciated relative to lithologically similar, but unaltered, sediments higher in the sedimentary sequence; (2) the dolerites were medium textured throughout, with 


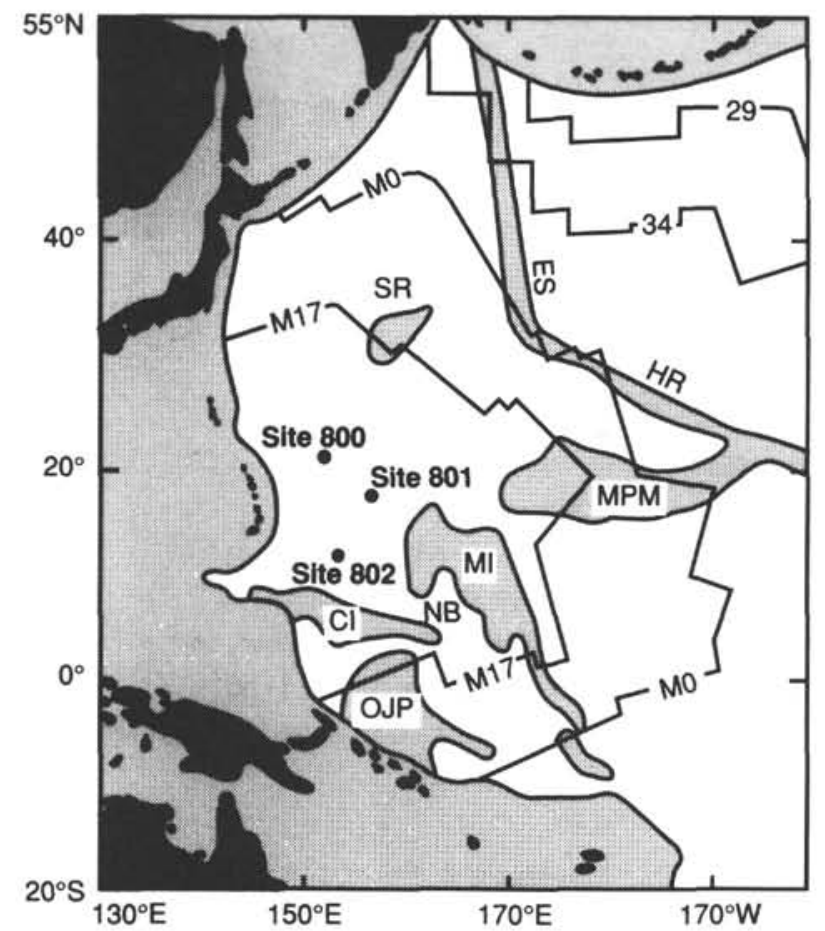

Figure 1. Map of the western Pacific Ocean showing the position of Leg 129 Sites 800, 801, and 802 (Lancelot, Larson, et al., 1990). Unshaded area represents normal Pacific ocean crust with magnetic lineation contours, whereas shaded areas represent thickened crustal sections and younger crust to the west of the Pacific subduction zones. Feature abbreviations are as follows: Caroline Islands (CI), Ontong-Java Plateau (OJP), Marshall Islands (MI), Nauru Basin (NB), Mid-Pacific Mountains (MPM), Shatsky Rise (SR), Hawaiian Ridge (HR) and Emperor Seamounts (ES)

finer-grained chilled margins, holocrystalline and nonvesicular quench textures and glassy margins characteristic of rapid cooling by seawater were conspicuously absent towards the margins; (3) the variable presence of late-stage secondary biotite and actinolite in all sills is interpreted as the result of contact metamorphism caused by sill intrusion. This feature is particularly well developed in the top of Unit 3 where both minerals replace earlier smectite-dominated alteration; and (4) magnetic results indicate that the least altered dolerites have a (primary) reversed polarity, whereas those portions affected by biotiteactinolite alteration exhibit a superimposed normal polarity which probably developed after initial emplacement.

The sills were emplaced into sediments of lowermost Cretaceous age (Berriasian) and on the basis of magnetic polarity correlations may have been intruded during pre- or early Aptian times (Lancelot, Larson, et al., 1990), whereas Ar-Ar dating (Pringle, this volume) indicate an intrusion age of $126 \mathrm{Ma}$. These data confirm the intrusive nature of the dolerites relative to the older enclosing sediments and their association with the mid-Cretaceous volcanic event.

\section{Primary and Secondary Petrography}

All three cooling units are represented by aphyric, nonvesicular, holocrystalline gray-green dolerites with medium-grained intersertal to interlocking textures. Background secondary alteration is dominated by smectite-carbonate-celadonite assemblages throughout. $\mathrm{Di}$ rectly below the basal sediments, however, Unit 1 is represented by a fine-grained highly altered basalt with a granular texture (chilled margin facies) and a reddish oxidized top that grades downwards into the more normal coarser-grained greenish dolerites.

Pale pink, poorly pleochroic titanaugite is the main mafic phase and forms stubby to elongate prims variable replaced by greenish smectites and carbonate, leaving large skeletal, optically-continuous relicts. No olivine or its pseudomorphs appear to be present, although a few rare ragged subhedral crystals of a pale brown primary amphibole are present in Unit 2. Albite-twinned plagioclase laths commonly exhibit normal zoning $\left(\mathrm{An}_{55-60}\right.$ to $\left.\mathrm{An}_{30-35}\right)$, although cores are often partially replaced by brownish smectite and opaque granular material (analcite or clays). Titanomagnetite is common throughout, forming small opaque granules in the finer grained portions of the dolerites and larger, variably corroded, subhedral grains and needles in the coarser interiors. At the top of Unit 1 this phase is completely oxidized to either red hematite or a limonitic stain that also impregnates adjacent smectites. Acicular apatite prisms are a common accessory throughout all units and the only primary phase to remain unaltered. Apart from patchy carbonate replacement, small alteration domains in the matrix are represented by either (1) granular dark brown smectite with pale green fibrous smectite, or (2) pale green fibrous smectite often with strong blue-green celadonite plates. In both cases, secondary biotite and actinolite may be seen concentrated in these domains and grow across them unaltered. This suggests that biotite and actinolite growth was later than the main smectite-dominated alteration and probably represents a higher grade of metamorphism superimposed on the dolerites by the thermal effects of adjacent intrusions. Biotite is more abundant than actinolite and may also nucleate on titanomagnetite grains. Rarely, biotite may be present as zoned euhedral plates with slightly darker rims relative to the optically uniform cores. In some highly altered domains, biotite plates may have ragged or splayed ends parting along the cleavage and are then partially replaced by blue-green celadonite or green smectite. This may reflect a subsequent alteration during cooling after thermal metamorphism.

The apparent lack of olivine and the generally intermediate nature of the plagioclase (andesine-labradorite) indicate that the dolerites are relatively evolved and (as substantiated by their major element chemistry) have an overall hawaiite composition rather than that of an alkali basalt.

\section{Site 802 Tholeiitic Lava Flows}

\section{Mode of Emplacement and Age}

The basalts of Hole $802 \mathrm{~A}$ are clearly extrusive submarine flows being characterized by numerous thin, nonvesicular cooling units (about $1 \mathrm{~m}$ or less) with quench textures throughout and glassy spherulitic margins. The preservation of typical rapid cooling textural zones and, in a number of cases, curved glassy selvages (Fig. 44 in Lancelot, Larson, et al., 1990) indicates that the sequence here is predominantly composed of a series of pillow lavas. Hole $802 \mathrm{~A}$, however, terminated in a coarser-grained, hypocrystalline unit which is considered to be a thin $(<5 \mathrm{~m})$ flow and thicker than most of the measurable units above. The top of the lava sequence is not extensively reddened and indicates that the time interval, before being covered by sediment, was relatively short so that alteration by oxygenated seawater was restricted. Glassy fragments spilled off the uppermost pillow lavas during cooling by seawater are incorporated into the basal sediments (volcanogenic claystones) of late Aptian age, and provide a minimum age for the lavas. Ar-Ar dating of the basalts gives an age of about $115 \mathrm{Ma}$ (Pringle, this volume) that corresponds to the uppermost Aptian (time scale by Harland et al., 1982).

\section{Primary and Secondary Petrography}

One of the features of the lava flow sequence at Hole 802A is that all cooling units are petrographically very similar, largely being composed of sparsely olivine-plagioclase or olivine-plagioclase-clinopyroxene microphyric tholeiitic basalts. However, up to about $20 \%$ of collected core is broadly aphyric, although even here scattered olivine and plagioclase phenocrysts may be encountered. Microphenocrysts are not uniformly distributed between or within cooling units, with some showing a concentration in the marginal highly quenched zones relative to the phenocryst-poor interiors. Larger 

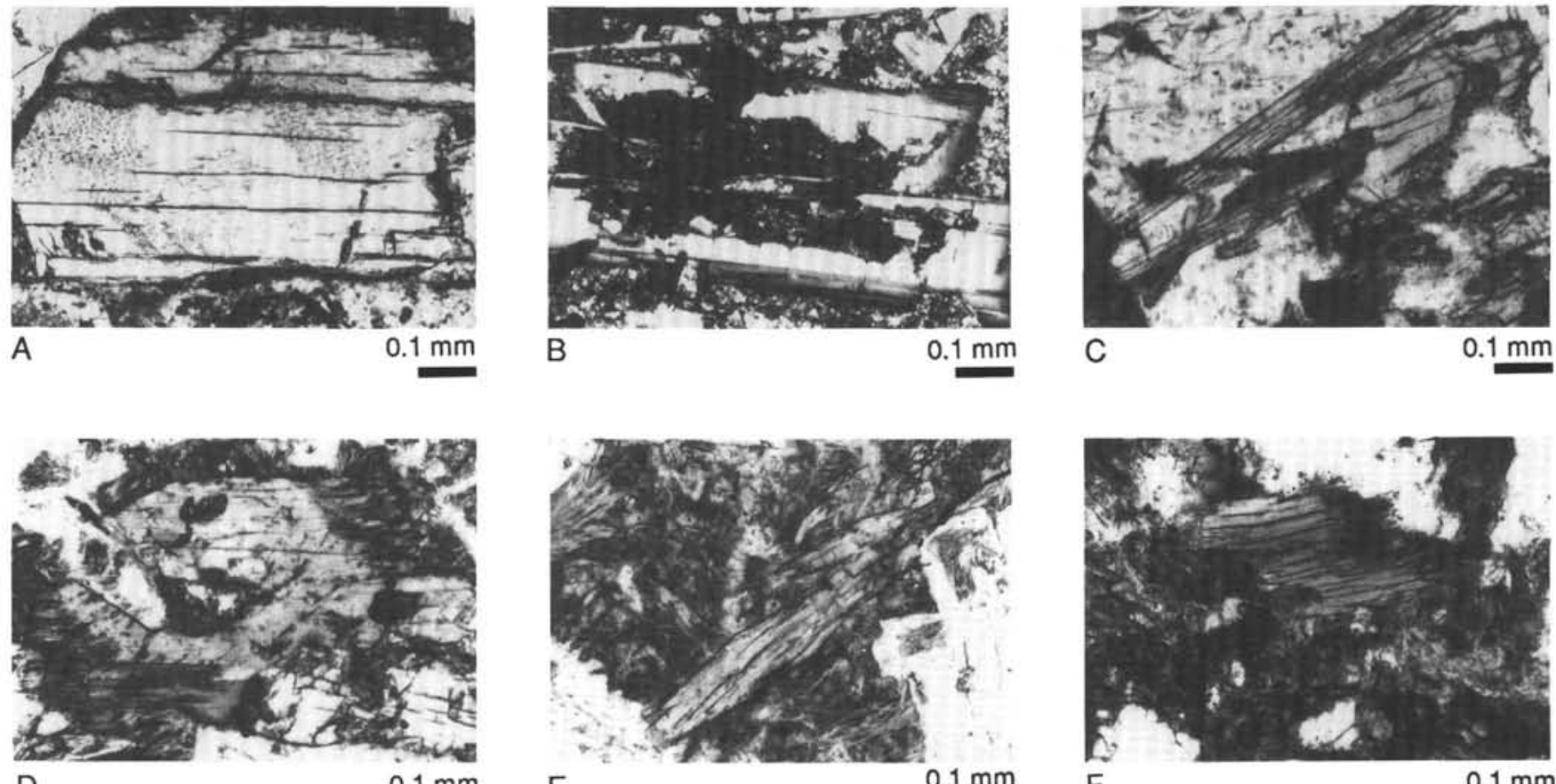

D

$0.1 \mathrm{~mm}$

E

$0.1 \mathrm{~mm}$

C

$0.1 \mathrm{~mm}$

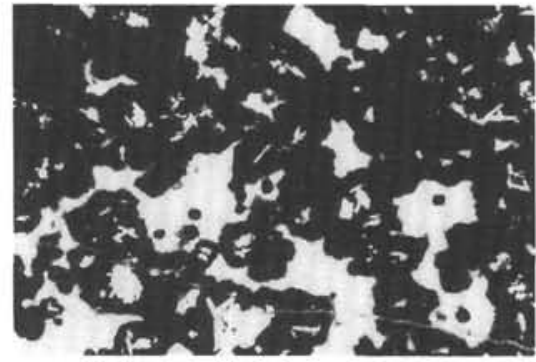

G

$0.5 \mathrm{~mm}$

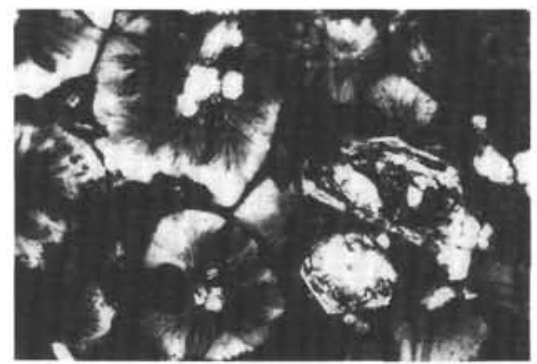

$\mathrm{H}$
$0.1 \mathrm{~mm}$

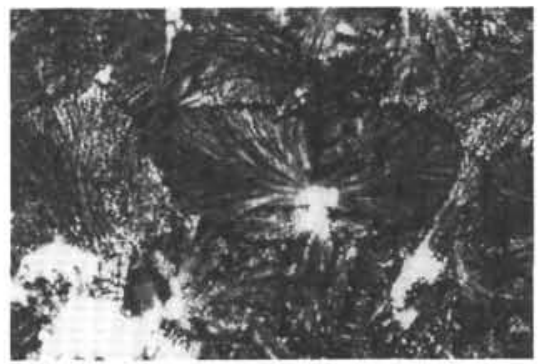

I

$0.1 \mathrm{~mm}$

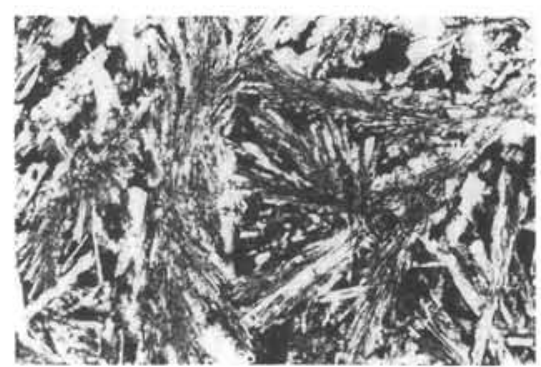

J

$0.1 \mathrm{~mm}$

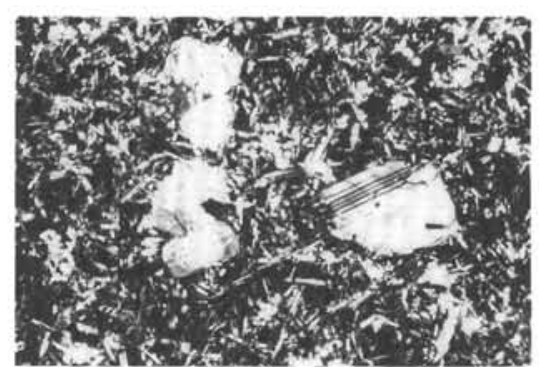

K

$0.5 \mathrm{~mm}$

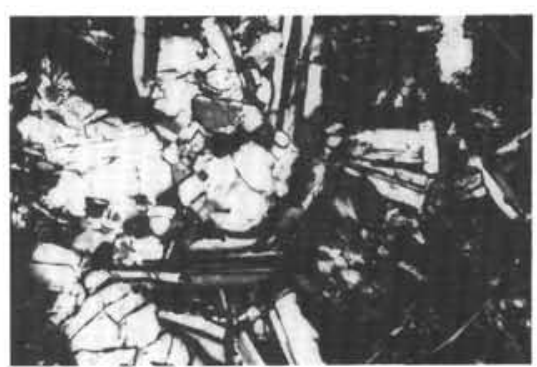

$\mathrm{L}$

$0.1 \mathrm{~mm}$

Figure 2. Photomicrographs illustrating petrographic and textural features of Site 800 alkalic dolerite sills (numbers 1-6) and Site 802 tholeiitic flows (numbers 7-12). $(\mathrm{ppl}=$ plane polarized light; $\mathrm{cp}=$ cross polars). A. Small brownish glass inclusions in titanaugite prism, Sample 129-800A-60R-1, 43-44 cm (ppl). B. Carlsbad twinned and zoned plagioclase lath with core replaced by dark granular smectite and analcite, Sample 129-800A-57R-2, 89-90 cm (cp). C. Acicular apatite crystals, Sample 129-800A-60R-1,71-74 cm (ppl). D. Large plate of poorly zoned actinolite with later fibrous fringe in brown smectite alteration domain, Sample 129-800A-58R-1, 46-47 cm (ppl). E. Primatic, fibrous actinolite growing unaltered across a brown smectite domain, Sample 129-800A-58R-1, 46-47 $\mathrm{cm}$ ( $\mathrm{ppl}$ ). F. Group of biotite plates in smectite alteration domain, with frayed terminations partially replaced by blue-green celadonite, Sample 129-800A-60R-1, 71-74 cm (ppl). G. Dark brown, partly coalesced spherulites nucleated on plagioclase microlites set in fresh glass (sideromelane), Sample 129-802A-58R-2. 145-149 cm (ppl). H. Smectite pseudomorphed olivine microphenocrysts in spherulitic zone of lava, Sample 129-802A-58R-2, 145-149 cm (ppl). I. Double-fan variolite growth on plagioclase microlite surrounded by opaque magnetite granules, Sample 129-802A-58R-4, 55-57 cm (ppl). J. Coarse sheaf and plumose variolites of clinopyroxene typical of the interior of flows, Sample 129-802A-57R-2, 126-128 cm (ppl). K. Group of clinopyroxene and zoned plagioclase phenocrysts, sample 129-802A-57R-2, 126-128 cm (cp). L. Glomerophyric cluster of anhedral clinopyroxene grains and plagioclase laths in quenched matrix, Sample 129-802A-57R-2, 126-128 cm (cp). 
dimensioned plagioclase phenocrysts (about $1 \mathrm{~mm}$ in length) may also be observed and are termed "megaphenocrysts" to distinguish them from the common smaller type.

Textural variation within units is largely the result of differential quenching by seawater, together with the random distribution of glomerophyric clumps and individual phenocrysts. Rapidly chilled selvages are glassy with variably coalesced spherulites that may often nucleate on plagioclase microlites, whereas the matrix of flow interiors grade from sheaf and plumous variolites to coarser intersertal and granular textures that may still exhibit quench morphologies (Fig. 2). Microphenocrysts of olivine are always replaced by brown fibrous smectite and occur as individual crystals scattered throughout both glassy and quenched crystal matrices. Plagioclase is often fresh and may be present as either broken and magmatically corroded zoned megacrysts (with cores of around $\mathrm{An}_{80}$ ), or, more usually, as microphenocrysts (commonly $\mathrm{An}_{65-70}$ ) in glomerophyric clumps with clinopyroxene. Clinopyroxene (augite) is rarely seen as individual "free" microphenocysts being invariably concentrated in glomerocrystic clumps. There are textural phenocryst associations that often characterize the more crystallized variolitic zone just below the glassy selvage of most units. On the one hand, there may be scattered, subhedral plagioclase megaphenocrysts and relatively abundant olivine microphenocrysts, whereas on the other are finer-grained glomerophyric clumps of quenched plagioclase laths and granular clinopyroxene. Both are set in a poorly birefringent matrix of brown plumous variolites and scattered magnetite granules. The two sizes of phenocryst imply different cooling histories, with the plagioclase megaphenocrysts and olivine developing in the magma chamber and the glomerophyric clumps at a higher level possibly just prior to actual extrusion. Any remaining melt on contact with seawater will then rapidly quench to produce a variolitic and/or glassy matrix. The textural diversity and association of glomerophyric clumps and variolites is common to all flows and is only replaced in the coarser interiors of larger cooling units with intersertal textures composed of granular clinopyroxene and serrated plagioclase laths, such as the thick olivine-plagioclase microphyric flow at the base of Hole 802A.

In terms of secondary alteration, the Cretaceous flows are remarkably fresh, being characterized by mainly smectite-carbonate-pyrite assemblages, both within the bulk rock and veins. This assemblage is typical of low-grade anoxic conditions. Color changes in various shades of gray within the core represent alteration haloes usually associated with areas of veining and more extensive matrix alteration by smectites. The preservation of fresh yellow sideromelane in some pillow selvages (for example, Sample 129-802A-58R-2, 99-102 cm) is rare, as most glass is replaced by brownish smectite. Olivine microphenocrysts are always pseudomorphed by brown smectites or in some glassy selvages by green smectite. Carbonate replacement is later than smectite alteration and occurs in a random, patchy fashion through the matrix. Plagioclase is sometimes replaced by carbonate, whereas clinopyroxene always remains fresh.

\section{GEOCHEMISTRY}

Major oxide and trace element data for Hole 800A dolerite sills and Hole 802A basalt lavas are shown in Tables 1 and 2, respectively. Analytical procedures and analysts are referenced in Floyd and Castillo (this volume). Geochemical data for both holes are plotted on the same diagrams to illustrate their main features and highlight the significant differences between the alkalic dolerites and tholeiitic basalts.

Apart from the main chemical differences between the alkalic dolerites and the tholeiitic basalts that are typical of their respective magma types, both groups feature very little chemical variation throughout the sampled sequences. This uniformity is also mirrored in the similarity of petrographic composition within each hole and may, in part, reflect the relatively short segment sampled in each case. However, small, relatively insignificant differences with depth (meters below sea floor, or mbsf) have been noted. The uppermost part of Hole $800 \mathrm{~A}$ (cooling Unit 1) is marginally more primitive (with slightly higher $\mathrm{Cr}$ and lower $\mathrm{Zr}$ abundances) than the rest of the section below (cooling Units 2 and 3 ), although there is no systematic variation with depth (Fig. 3). Hole 802A, on the other hand, shows a chemical break in $\mathrm{Zr}$ content at $536 \mathrm{mbsf}$ (Fig. 3) that corresponds to the boundary between cooling Units 14 and 15 . Both the lower and upper chemical groups show a poorly defined trend towards higher $\mathrm{Zr}$ values with height in the "basement" (the highest value of $101 \mathrm{ppm} \mathrm{Zr}$ being at the top of cooling Unit 1). The significance of the $\mathrm{Zr}$ hiatus is not clear as other stable trace elements (incompatible and compatible) do not show this feature as strongly as $\mathrm{Zr}$ (Fig. 3) and the lavas above and below show broadly the same petrographic variation throughout.

The development of secondary minerals is a common feature of both Holes, and in particular, influences the distribution of most large-ionlithophile (LIL) elements (for example, Humphris and Thompson, 1978). Hole $800 \mathrm{~A}$ alkalic dolerites are more hydrated (higher $\mathrm{H}_{2} \mathrm{O}+$ ) and oxidized (higher $\mathrm{Fe}_{2} \mathrm{O}_{3} / \mathrm{FeO}$ ratio) than the mildly altered Hole $802 \mathrm{~A}$ tholeitic basalts (Fig. 4). Part of the high water content of the former group probably reflects the presence of extensive contact metamorphic biotite. Both groups exhibit considerable non-magmatic variation in their LIL-element contents and with ratios indicative of low-grade submarine alteration rather than the effect of magmatic processes; for example $\mathrm{K} / \mathrm{Rb}$ ratios range from 400-1300 (Hole 800A dolerites) and 160-950 (Hole $802 \mathrm{~A}$ basalts).

The Cretaceous alkalic dolerites (Hole 800A) and tholeiitic basalts (Hole 802A) exhibit the following primary chemical features (Figs. 5 and 6):

1. As might be expected all the alkalic dolerites are markedly enriched in incompatible elements (except $\mathrm{Y}$ ) and exhibit different incompatible element ratios to the tholeiitic basalts. For example, alkalic dolerites have $\mathrm{Zr}$ contents $>300 \mathrm{ppm}$ and $\mathrm{Zr} / \mathrm{Y}$ ratios of $13-16$, whereas the tholeiitic basalts have about $60-70 \mathrm{ppm} \mathrm{Zr}$ and very low $\mathrm{Zr} / \mathrm{Y}$ ratios between 2.5-2.8.

2. Both dolerites and basalts are characterized by very narrow ranges of incompatible elements such that both suites show little chemical variation (Fig. 5) and feature relatively uniform incompatible element ratios. Compatible elements, such as $\mathrm{Cr}$ and $\mathrm{Ni}$, show a slightly greater diversity (Fig. 5) and together with a moderate range of $\mathrm{FeO}^{*} / \mathrm{MgO}$ ratios for dolerites $(0.8-2.0)$ and basalts (1.0-1.6), indicate that only very minor mafic fractionation (olivine and clinopyroxene) has taken place throughout both groups. Compare, for example, the range in elemental compositions exhibited by tholeiitic lavas from the Nauru Basin and Ontong-Java plateau with that of Hole 802A tholeiites (Fig. 5).

3. Although chondrite-normalized rare earth element (REE) patterns (Fig. 6) are dissimilar for the alkalic dolerites and tholeiitic basalts, the range of variation and degree of REE fractionation is again very limited in each group. The dolerites show strong light REE enriched patterns, with $(\mathrm{La} / \mathrm{Yb})_{\mathrm{N}}$ from 17.5-20.0, whereas most of the basalts are characterized by relatively flat REE patterns $\left([\mathrm{La} / \mathrm{Yb}]_{\mathrm{N}}\right.$ $0.9-1.2$ ) with about 10-12 times the chondritic abundances. Some of the slightly more fractionated samples (with lowest $\mathrm{Cr}$ and $\mathrm{Ni}$ ) exhibit minor light REE enrichment $\left([\mathrm{La} / \mathrm{Yb}]_{\mathrm{N}} 1.5-2.0\right)$ that is a function of clinopyroxene fractionation. However, the general similarity and parallelism of the REE patterns in both dolerites and basalts reflects the precipitation of phases that do not fractionate the REE to any degree and conforms with the observed presence of olivine and plagioclase as phenocrystic phases.

In general terms, the incompatible element-enriched features of the alkalic dolerites are characteristic of ocean island basalts (OIB). Although the low abundances of these elements and their distinctive ratios in the tholeiitic basalts are akin to some types of mid-ocean ridge basalt (MORB) (Bougault et al., 1980; Saunders, 1984), their flat REE patterns distinguishes them from typical N-type MORB. These distinctive chemical features find their counterpart in clearly 
different isotopic ratios, which implies the two groups were derived from different mantle sources (Castillo et al., this volume). This is substantiated by markedly different ratios of highly incompatible elements $(\mathrm{La}, \mathrm{Nb}, \mathrm{Ta}, \mathrm{Th})$ that reflect the nature of the source rather than variable mantle melting (Bougault et al., 1979). For example, $\mathrm{La} / \mathrm{Th}$ and La/Ta ratios are consistently higher in the basalts (about 15 and 18 , respectively) than the dolerites (about 10 and 12.5 , respectively).

\section{ERUPTIVE ENVIRONMENT AND ORIGIN}

In this section we consider the general geochemical features of the dolerites and basalts in an attempt to determine their tectonic setting relative to other basic submarine volcanics, especially those considered part of the widespread mid-Cretaceous volcanic event. In terms of age and postulated eruptive setting, both Hole 800A dolerites and Hole $802 \mathrm{~A}$ basalts are strong contenders for additional expressions of mid-Cretaceous volcanism (Lancelot, Larson, et al., 1990).

\section{Alkalic Dolerite Sills}

Thick massive doleritic units, generally interpreted as sills, have been drilled in a number of deep sea locations in both the Atlantic and Pacific oceans (for example, Leg 43, Tucholke, Vogt, et al., 1979; Leg 58, deVries Klein, Kobayashi, et al., 1980; Leg 61, Larson, Schlanger, et al., 1981; Leg 64, Curray, Moore, et al., 1982), although with a few exceptions most have tholeiitic compositions. Sills forming part of the oceanic crust of small basins, such as the Gulf of California (Saunders et al., 1982) and the Daito and Shikoku basins in the western Pacific (Marsh et al., 1980) are mainly tholeiites, although in a few cases relatively abundant alkalic basalt units may be present, such as in Hole 446A (Daito Basin). In the deeper water, open ocean environment, such as the Nauru Basin, the upper portion of the basaltic sequence constitutes a series of sills, although again they are tholeiitic in composition (Floyd, 1989). In some cases submarine sills appear to be closely associated with seamounts or ocean islands. For example, alkalic sills with high incompatible element contents (200-400 Zr ppm) were recovered from Leg 43 (Houghton, 1979), some of which were developed on the flanks of the New England Seamounts. In the Central Pacific Basin various doleritic rocks (some considered to be sills) with an alkalic parentage and containing primary brown amphibole and biotite, were probably derived from the nearby Line Islands or adjacent seamounts (Bass et al., 1973). It is apparent that the alkalic composition of some sills and their relatively close geographic position to nearby seamounts and ocean islands suggests they may be structurally related and form minor intrusions on their flanks. A seamount model based on the dissected La Palma Seamount Series (Canary Islands) suggests that small sill-like intrusions are a feature of early development and may well extend out beyond the seamount base (Staudigel and Schmincke, 1984).

As there is little chemical data on submarine Cretaceous-aged alkalic sills, we have compared the Hole $800 \mathrm{~A}$ sills with oceanic islands, seamounts, and submarine sills of different ages but of alkalic origin. As seen in Figure 7, alkalic basalts from submarine sills show good covariance for individual suites, with $\mathrm{Ti} / \mathrm{Zr}$ ratios ranging between 120 and 59. Note that the upper sequence Jurassic alkalic dolerites from Site 801 also plot within this range. Probably because of the opportunity to sample a wider range of material, oceanic island alkalic basalts, on the other hand, show a far wider range of $\mathrm{TiO}_{2}$ and $\mathrm{Zr}$ abundances, with a $\mathrm{TiO}_{2}$ peak that roughly separates the strictly basaltic compositions from the more evolved basic differentiates. The Hole $800 \mathrm{~A}$ dolerites also show a minor peaked pattern (due to titanomagnetite fractionation), but differ from the "main alkalic array" with very low $\mathrm{Ti} / \mathrm{Zr}$ ratios (about 36 ). In comparison the apparently evolved compositions of Hole 800A dolerites are also supported by the petrography (see above) which indicates that they are mainly of hawaiite composition. The dolerites also differ from other OIB in exhibiting highly fractionated REE patterns (Fig. 6) with $(\mathrm{La} / \mathrm{Yb})_{\mathrm{N}}$ ratios of between 18-21. As shown in Figure 8, these sills are more fractionated than most OIB alkalic rocks and are only matched by some of the Society Seamount lavas (Devey et al., 1990). Other incompatible element ratios are also distinctive, such as high $\mathrm{Zr} / \mathrm{Y}$ (about 14 ) and $\mathrm{La} / \mathrm{Th}$ (about 10 ) relative to other OIB, as well as to the Site 801 alkalic dolerites.

On the basis of the above data, the Site 800 alkalic dolerites have a chemical identity of their own, but are more akin to evolved alkalic OIB from islands and seamounts than alkalic basalts that appear to form part of the oceanic basement (for example Site 801). The particular chemistry of the alkalic dolerite (especially the high $(\mathrm{La} / \mathrm{Yb})_{\mathrm{N}}$ and $\mathrm{Zr} / \mathrm{Y}$ ratios) may suggest that their parental composition was generated by smaller degrees of partial melting relative to some of the other OIB, or that the source was generally more enriched in some incompatible elements. Site 800 is surrounded by a number of seamounts including Himu and Golden Dragon, both of which have isotopically distinctive compositions with a high proportion of the HIMU mantle end member and are almost isotopically identical to the Site 800 alkalic dolerites (Castillo et al, this volume). A HIMU component is also suggested by the specific chemical composition of the dolerites, such as the low $\mathrm{Ba} / \mathrm{Nb}$ ratio (c. 5-8). As demonstrated by Sun and McDonough (1989) low $\mathrm{Ba} / \mathrm{Nb}$ ratios correlate with low ${ }^{87} \mathrm{Sr} /{ }^{86} \mathrm{Sr}$ ratios that are generally typical of OIB with a HIMU component relative to other OIB with enriched mantle (EMI and EMII) components.

Both chemical and isotopic parameters suggest the dolerite sills are tapping the same mantle source as some of the nearby seamounts. In view of the seamount-sill relationships suggested elsewhere, Site 800 sills may also be volcanologically and genetically related, representing deep intrusive offshoots from the seamount flanks. Site 800 is surrounded by seamounts between $50-120 \mathrm{~km}$ away (Fig. 2, Lancelot, Larson, et al., 1990) and well within the distance of possible volcanic activity associated with active ocean islands. For example, the widespread alkalic volcanism associated with the Hawaiian South Arch (Lipman et al., 1989) occurs c. $200 \mathrm{~km}$ to the south of Hawaii Island, and in a similar manner the Site 800 sills may represent leakage of flank melts from plumes feeding the adjacent seamounts.

\section{Tholeiitic Basalt Lavas}

The extrusive pillow lavas of Site 802 with an age of about $115 \mathrm{Ma}$ are probably a deep-sea expression of the mid-Cretaceous volcanic event, especially as they are about $50 \mathrm{~m}$.y. younger than that predicted for the basement (mid-Jurassic) in this part of the Mariana Basin (Lancelot, Larson, et al., 1990). Apart from numerous seamounts generated in mainly Aptian times, large-scale volcanic provinces in the western Pacific generated during the mid-Cretaceous include Nauru Basin and various oceanic plateaus, such as Ontong-Java, Manihiki, Hess Rise etc. (Winterer, 1973; Schlanger et al., 1981). These submarine provinces are generally considered to represent episodes of crustal thickening soon after or as a continuation of axial activity (Saunders, 1986; Mahoney, 1987) generated above the inflated heads of large mantle plumes during the early Cretaceous (Richards et al., 1989). The tholeiitic basalts of the oceanic plateaus have a broad MORB-like geochemistry, although they exhibit a number of distinctive features that set them apart (Batiza et al., 1980; Floyd, 1989). In particular they are enriched in LIL elements, are characterized by generally flat (or less depleted) REE patterns and have different incompatible element ratios, in particular lower $\mathrm{Zr} / \mathrm{Nb}$, $\mathrm{Zr} / \mathrm{Ta}, \mathrm{La} / \mathrm{Ta}$, and $\mathrm{Hf} / \mathrm{Th}$, relative to normal-type mid-ocean ridge basalt (N-MORB).

Chemical tectonic environment discrimination diagrams, such as Hf-Ta-Th (Wood, 1980), Nb-Y-Zr (Meschede, 1986), and $\mathrm{Zr} / \mathrm{Y}-\mathrm{Zr}$ (Pearce and Norry, 1979), all group the Site 802 basalts as N-MORB. However, in this case, these diagrams are unreliable as the basalts are characterized by (1) flat REE patterns (Fig. 6) and (2) normalized multi-element distributions exhibiting LIL element and Nb-Ta enrichment (Fig. 9) relative to N-MORB. Highly incompatible element ratios are also different (Fig. 10) to Jurassic N-MORB (Site 801) with 
Table 1. Major oxide and trace element data for Hole $800 \mathrm{~A}$ alkalic dolerite sills.

\begin{tabular}{|c|c|c|c|c|c|c|c|c|c|c|c|c|c|}
\hline Core, section: & $57 \mathrm{R}-1$ & $57 R-1$ & $57 \mathrm{R}-2$ & $58 \mathrm{R}-1$ & $58 \mathrm{R}-1$ & $58 \mathrm{R}-1$ & $58 \mathrm{R}-2$ & $58 \mathrm{R}-2$ & $58 \mathrm{R}-2$ & $58 \mathrm{R}-2$ & $58 \mathrm{R}-2$ & $58 \mathrm{R}-3$ & $59 \mathrm{R}-1$ \\
\hline Interval $(\mathrm{cm})$ : & $17-24$ & $40-45$ & $86-91$ & $12-17$ & $47-51$ & $86-91$ & $32-37$ & $67-73$ & $52-60$ & $106-110$ & $142-150$ & $35-41$ & $4-9$ \\
\hline Depth (mbsf): & 498.17 & 498.40 & 499.36 & 507.32 & 507.67 & 508.06 & 508.05 & 509.20 & 509.35 & 509.59 & 509.95 & 510.38 & 516.64 \\
\hline Cooling unit: & Al & Al & Al & Al & A2 & A3 & $\mathrm{A} 3$ & A3 & A3 & A3 & A3 & A3 & A3 \\
\hline \multicolumn{14}{|c|}{ Major oxides (wt\%) } \\
\hline $\mathrm{SiO}_{2}$ & 49.56 & 45.72 & 49.09 & 49.34 & 49.88 & 50.60 & 48.94 & 50.40 & 50.52 & 50.32 & 51.21 & 51.22 & 49.73 \\
\hline $\mathrm{TiO}_{2}$ & 2.17 & 1.95 & 2.01 & 2.19 & 2.21 & 2.13 & 2.11 & 2.13 & 2.23 & 2.03 & 2.04 & 2.14 & 2.17 \\
\hline $\mathrm{Al}_{2} \mathrm{O}_{3}$ & 15.86 & 14.77 & 15.97 & 15.91 & 15.69 & 15.89 & 15.83 & 16.00 & 16.15 & 15.96 & 16.22 & 16.56 & 15.92 \\
\hline $\mathrm{Fe}_{2} \mathrm{O}_{3}$ & 9.01 & 6.84 & 5.63 & 4.51 & 5.55 & 4.58 & 5.72 & 4.89 & 4.71 & 6.47 & 4.87 & 4.14 & 4.50 \\
\hline $\mathrm{FeO}$ & 0.37 & 1.06 & 2.82 & 4.92 & 4.01 & 5.12 & 3.78 & 4.86 & 4.60 & 3.38 & 4.30 & 4.84 & 5.30 \\
\hline $\mathrm{MnO}$ & 0.15 & 0.12 & 0.07 & 0.15 & 0.15 & 0.19 & 0.20 & 0.15 & 0.18 & 0.16 & 0.19 & 0.21 & 0.16 \\
\hline $\mathrm{MgO}$ & 5.04 & 4.01 & 7.92 & 6.72 & 6.767 & 6.44 & 6.46 & 6.73 & 6.31 & 6.73 & 6.42 & 6.12 & 6.31 \\
\hline $\mathrm{CaO}$ & 3.96 & 10.27 & 4.83 & 6.00 & 4.53 & 5.92 & 6.34 & 4.89 & 4.74 & 3.92 & 4.75 & 5.20 & 5.44 \\
\hline $\mathrm{Na}_{2} \mathrm{O}$ & 2.66 & 3.63 & 2.94 & 3.92 & 3.86 & 4.12 & 4.07 & 3.87 & 4.05 & 3.79 & 4.07 & 4.41 & 4.22 \\
\hline $\mathrm{K}_{2} \mathrm{O}$ & 5.64 & 3.69 & 3.22 & 2.55 & 0.62 & 0.54 & 0.55 & 0.53 & 0.56 & 2.93 & 2.92 & 2.24 & 1.94 \\
\hline $\mathrm{P}_{2} \mathrm{O}_{5}$ & 0.55 & 0.55 & 0.56 & 0.54 & 0.62 & 0.54 & 0.55 & 0.53 & 0.56 & 0.46 & 0.63 & 0.48 & 0.55 \\
\hline LOI & 4.94 & 8.04 & 5.30 & 3.49 & 3.21 & 2.63 & 3.50 & 2.77 & 2.93 & 3.54 & 2.62 & 2.15 & 3.65 \\
\hline Total & 99.92 & 100.64 & 100.38 & 100.26 & 99.36 & 100.42 & 99.46 & 99.99 & 99.74 & 99.70 & 100.23 & 99.71 & 99.89 \\
\hline $\mathrm{H}_{2} \mathrm{O}+$ & 3.38 & 2.21 & 3.61 & 2.38 & 3.04 & 2.13 & 2.50 & 2.41 & 2.49 & 3.14 & 2.22 & 1.97 & 2.70 \\
\hline $\mathrm{CO}_{2}$ & 1.34 & 5.10 & 1.38 & 1.18 & 0.22 & 0.60 & 0.64 & 0.38 & 0.34 & 0.18 & 0.16 & 0.12 & 0.43 \\
\hline \multicolumn{14}{|c|}{ Trace elements by XRF (ppm) } \\
\hline $\mathrm{Ba}$ & 475 & 251 & 339 & 337 & 388 & 317 & 368 & 359 & 402 & 421 & 413 & 316 & 391 \\
\hline $\mathrm{Ce}$ & 95 & 74 & 109 & 81 & 104 & 80 & 95 & 91 & 80 & 111 & 81 & 88 & 90 \\
\hline $\mathrm{Cr}$ & 203 & 140 & 127 & 134 & 80 & 155 & 81 & 120 & 82 & 81 & 93 & 326 & 38 \\
\hline $\mathrm{Cu}$ & 63 & 30 & 65 & 54 & 24 & 36 & 83 & 74 & 42 & 43 & 65 & 64 & 38 \\
\hline $\mathrm{Ga}$ & 21 & 22 & 23 & 22 & 22 & 22 & 24 & 24 & 22 & 24 & 23 & 24 & 21 \\
\hline $\mathrm{La}$ & 48 & 31 & 54 & 31 & 52 & 31 & 41 & 44 & 43 & 61 & 29 & 42 & 39 \\
\hline $\mathrm{Nb}$ & 52 & 48 & 50 & 51 & 54 & 53 & 53 & 51 & 55 & 58 & 56 & 56 & 58 \\
\hline $\mathrm{Nd}$ & 56 & 37 & 60 & 27 & 58 & 35 & 45 & 49 & 45 & 65 & 40 & 48 & 38 \\
\hline $\mathrm{Ni}$ & 122 & 83 & 82 & 42 & 43 & 41 & 46 & 44 & 39 & 43 & 43 & 42 & 39 \\
\hline $\mathrm{Pb}$ & 3 & 4 & 1 & 1 & 1 & 2 & 2 & 2 & 1 & 3 & 3 & 1 & 1 \\
\hline $\mathrm{Rb}$ & 93 & 82 & 20 & 31 & 22 & 19 & 24 & 25 & 23 & 27 & 29 & 28 & 21 \\
\hline S & 123 & 128 & 1054 & 273 & 263 & 332 & 421 & 315 & 305 & 268 & 274 & 271 & 350 \\
\hline $\mathrm{Sr}$ & 340 & 466 & 493 & 566 & 525 & 608 & 578 & 548 & 544 & 473 & 526 & 597 & 574 \\
\hline V & 165 & 188 & 185 & 187 & 183 & 186 & 192 & 187 & 185 & 190 & 154 & 211 & 189 \\
\hline $\mathrm{Y}$ & 22 & 25 & 23 & 27 & 27 & 26 & 25 & 25 & 25 & 24 & 25 & 25 & 25 \\
\hline $\mathrm{Zn}$ & 137 & 80 & 144 & 77 & 101 & 72 & 117 & 82 & 104 & 114 & 90 & 96 & 115 \\
\hline $\mathrm{Zr}$ & 348 & 330 & 340 & 356 & 360 & 390 & 362 & 344 & 379 & 390 & 400 & 394 & 386 \\
\hline \multicolumn{14}{|c|}{ Trace elements by INAA (ppm) } \\
\hline Cs & - & 3.53 & 0.14 & 0.15 & 0.15 & - & - & 0.10 & 0.06 & 0.10 & - & 0.10 & - \\
\hline $\mathrm{Hf}$ & - & 7.51 & 7.12 & 7.70 & 8.10 & - & - & 8.10 & 8.29 & 8.19 & - & 8.30 & - \\
\hline $\mathrm{Sc}$ & - & 16.3 & 17.8 & 20.3 & 18.6 & - & - & 19.1 & 18.0 & 17.1 & - & 19.3 & - \\
\hline $\mathrm{Ta}$ & - & 3.18 & 3.21 & 3.26 & 3.33 & - & - & 3.19 & 3.53 & 3.71 & - & 3.63 & - \\
\hline Th & - & 3.57 & 3.64 & 4.20 & 4.30 & - & - & 4.10 & 4.06 & 4.22 & - & 4.60 & - \\
\hline $\mathrm{U}$ & - & 1.93 & 1.58 & 1.25 & 1.23 & - & - & 1.23 & 1.37 & 1.48 & - & 1.39 & - \\
\hline \multicolumn{14}{|c|}{ Rare earth elements (ppm) } \\
\hline $\mathrm{La}$ & - & 37.10 & 36.50 & 43.06 & 46.07 & - & - & 43.60 & 41.40 & 39.00 & - & 45.99 & - \\
\hline $\mathrm{Ce}$ & - & 79.80 & 78.30 & 87.32 & 93.87 & - & - & 89.00 & 86.60 & 80.40 & - & 92.56 & - \\
\hline $\operatorname{Pr}$ & - & - & - & 9.90 & 10.81 & - & - & 10.06 & - & - & - & 10.53 & - \\
\hline $\mathrm{Nd}$ & - & 36.00 & 37.00 & 40.25 & 43.77 & - & - & 40.34 & 38.00 & 37.00 & - & 41.51 & - \\
\hline $\mathrm{Sm}$ & - & 7.96 & 7.75 & 7.96 & 8.4 & - & - & 7.80 & 8.34 & 7.58 & - & 7.85 & - \\
\hline $\mathrm{Eu}$ & - & 2.48 & 2.46 & 2.57 & 2.72 & - & - & 2.58 & 2.64 & 2.38 & - & 2.57 & - \\
\hline $\mathrm{Gd}$ & - & - & - & 6.84 & 7.44 & - & - & 6.87 & - & - & - & 6.85 & - \\
\hline $\mathrm{Tb}$ & - & 0.94 & 0.87 & - & - & - & - & - & 0.945 & 0.882 & - & - & - \\
\hline Dy & - & - & - & 5.33 & 5.55 & - & - & 5.27 & - & - & - & 5.37 & - \\
\hline Ho & - & - & - & 0.86 & 0.91 & - & - & 0.86 & - & - & - & 0.88 & - \\
\hline $\mathrm{Er}$ & - & - & - & 2.25 & 2.36 & - & - & 2.25 & - & - & - & 2.36 & - \\
\hline $\mathrm{Yb}$ & - & 1.44 & 1.29 & 1.67 & 1.59 & - & - & 1.55 & 1.50 & 1.48 & - & 1.67 & - \\
\hline $\mathrm{Lu}$ & - & 0.197 & 0.177 & 0.26 & 0.24 & - & - & 0.24 & 0.204 & 0.201 & - & 0.26 & - \\
\hline
\end{tabular}

Note: Dash (-) indicates element not determined.

values intermediate to more enriched types, such as transitional MORB from the FAMOUS area of the Mid-Atlantic Ridge. Note that the only Pacific MORB with $\mathrm{Zr} / \mathrm{T}$ a ratios similar to the Site 802 basalts is from a failed rift (the Mendoza Rise), off the East Pacific Rise, drilled during Leg 92 (Leinen, Rea, et al., 1986). Although the basalts from Site 597 of this Leg have many depleted MORB-type characteristics (Pearce et al., 1986) they are very different to most Pacific and Atlantic N-MORB in terms of ratios of highly incompatible elements as seen in Figure 10. However, in many cases incompatible element ratios overlap or are similar in the Site 802 lavas to the Nauru Basin and Ontong-Java tholeiites. Compatible element contents are also generally similar at the same level of magmatic evolution, although the range of $\mathrm{Cr}$ and $\mathrm{Ni}$ contents (up to high values) is not seen at Site 802 . Isotopic ratios $(\mathrm{Sr}, \mathrm{Nd}$, and $\mathrm{Pb}$ ) are also comparable to the Nauru Basin basalts (Castillo et al., this volume).

Overall, the Site 802 pillow lavas are chemically similar to other large-volume mid-Cretaceous volcanic provinces in the Pacific Ocean and we suggest that they represent a further example of this widespread 
Table 1 (continued).

\begin{tabular}{|c|c|c|c|c|}
\hline $60 \mathrm{R}-1$ & $60 R-1$ & $60 \mathrm{R}-1$ & $61 \mathrm{R}-1$ & $61 R-1$ \\
\hline $15-20$ & $44-46$ & $69-74$ & $10-16$ & $17-24$ \\
\hline 526.05 & 526.30 & 526.59 & 535.40 & 535.47 \\
\hline A3 & $\mathrm{A} 3$ & A3 & A3 & A3 \\
\hline 49.90 & 50.67 & 50.80 & 50.68 & 50.21 \\
\hline 2.12 & 2.14 & 2.09 & 2.12 & 2.29 \\
\hline 16.06 & 16.11 & 16.09 & 15.99 & 15.99 \\
\hline 4.33 & 5.27 & 5.66 & 4.89 & 4.99 \\
\hline 4.96 & 4.87 & 3.85 & 4.86 & 4.89 \\
\hline 0.14 & 0.16 & 0.14 & 0.12 & 0.12 \\
\hline 6.36 & 6.48 & 6.75 & 6.53 & 6.67 \\
\hline 5.94 & 5.00 & 4.64 & 5.26 & 5.05 \\
\hline 4.04 & 4.00 & 4.02 & 4.04 & 4.06 \\
\hline 2.29 & 2.50 & 2.49 & 2.29 & 2.33 \\
\hline 0.48 & 0.55 & 0.46 & 0.47 & 0.60 \\
\hline 3.17 & 2.51 & 3.23 & 2.59 & 3.04 \\
\hline 99.78 & 100.26 & 100.22 & 99.83 & 100.24 \\
\hline 2.22 & 1.88 & 2.50 & 2.20 & 2.83 \\
\hline 0.95 & 0.20 & 0.16 & 0.29 & 0.20 \\
\hline 308 & 380 & 419 & 331 & 371 \\
\hline 92 & 104 & 71 & 92 & 96 \\
\hline 114 & 107 & 64 & 333 & 48 \\
\hline 32 & 77 & 49 & 22 & 24 \\
\hline 22 & 23 & 24 & 21 & 21 \\
\hline 41 & 44 & 31 & 47 & 36 \\
\hline 52 & 54 & 55 & 52 & 55 \\
\hline 48 & 54 & 34 & 48 & 41 \\
\hline 43 & 44 & 44 & 43 & 39 \\
\hline 2 & 3 & 1 & 1 & 1 \\
\hline 25 & 27 & 24 & 25 & 23 \\
\hline 194 & 334 & 263 & 159 & 168 \\
\hline 585 & 559 & 518 & 572 & 542 \\
\hline 181 & 178 & 184 & 200 & 194 \\
\hline 24 & 27 & 24 & 25 & 26 \\
\hline 76 & 95 & 111 & 85 & 111 \\
\hline 357 & 370 & 379 & 356 & 363 \\
\hline 0.11 & 0.09 & 0.07 & 0.10 & 0.11 \\
\hline 7.80 & 8.03 & 7.87 & 8.50 & 7.83 \\
\hline 17.4 & 19.4 & 17.4 & 20.6 & 15.6 \\
\hline 3.36 & 3.45 & 3.46 & 3.40 & 3.50 \\
\hline 4.40 & 3.99 & 3.98 & 4.40 & 4.06 \\
\hline 1.25 & 1.43 & 1.36 & 1.22 & 1.27 \\
\hline 43.90 & 39.00 & 36.00 & 42.37 & 40.40 \\
\hline 89.16 & 81.80 & 76.20 & 85.60 & 85.40 \\
\hline 9.95 & - & - & 9.78 & - \\
\hline 39.71 & 40.00 & 36.00 & 38.00 & 41.00 \\
\hline 7.52 & 7.96 & 7.51 & 7.42 & 8.36 \\
\hline 2.50 & 2.53 & 2.43 & 2.51 & 2.60 \\
\hline 6.57 & - & - & 6.69 & - \\
\hline- & 0.950 & 0.883 & - & 0.964 \\
\hline 5.22 & - & - & 5.26 & - \\
\hline 0.85 & - & - & 0.86 & - \\
\hline 2.29 & - & - & 2.31 & - \\
\hline 1.63 & 1.52 & 1.42 & 1.63 & 1.57 \\
\hline 0.26 & 0.215 & 0.197 & 0.26 & 0.219 \\
\hline
\end{tabular}

volcanic event. Isotopically, Site 801 lavas fall outside typical Pacific MORB compositions (Castillo et al., this volume) and are similar to large oceanic plateaus (Castillo et al., 1991; Mahoney and Spencer, 1991) with OIB-like compositions. They differ, however, in volcanological development and environment to the oceanic plateaus (that appreciably thicken the oceanic crust near spreading axes), in that the Site 802 basalts probably represent a thin veneer over the local Jurassic crust and were developed in an off-axis environment a considerable time after the local basement was formed. An alternative (but less likely) possibility is that Site 802 tholeiites actually represent

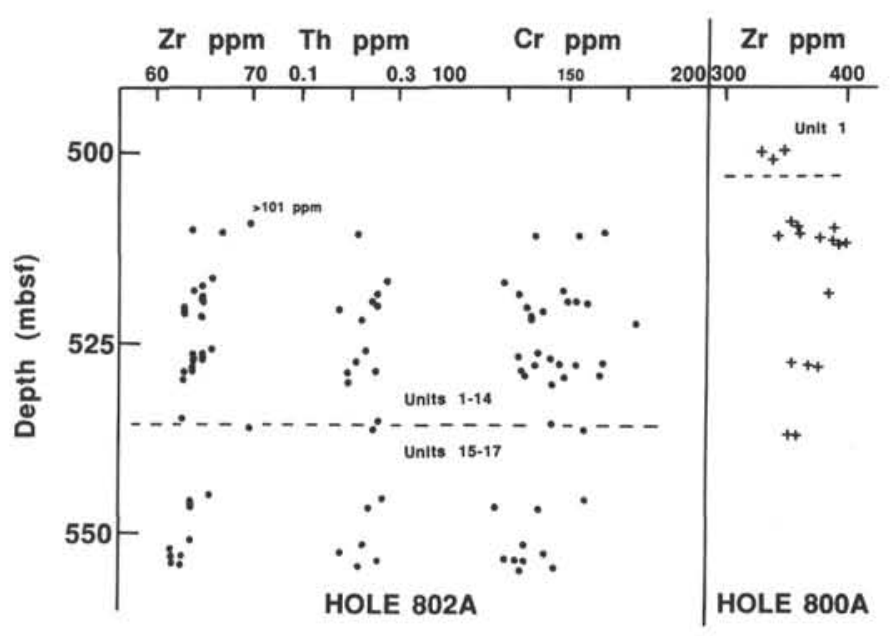

Figure 3. Distribution of $\mathrm{Zr}$, Th, $\mathrm{Cr}$ (Hole 802A) and $\mathrm{Zr}$ (Hole 800A) with depth below sea floor (mbsf). The $\mathrm{Zr}$ hiatus in Hole $802 \mathrm{~A}$ occurs between cooling Units 14 and 15, although this is not marked by other trace elements, such as $\mathrm{Th}$ and $\mathrm{Cr}$.

enriched ocean crust in the East Mariana Basin, developed and focussed by the local rifting of pre-existing Jurassic crust (for example, Castillo et al., 1991). Whatever the case, the nature of the mantle was represented by an enriched MORB-source composition, rather than a typically depleted composition.

\section{ACKNOWLEDGMENTS}

Thanks are due to co-chiefs Roger Larson and Yves Lancelot for impressing on us the extent of the mid-Cretaceous volcanic event in the Pacific and the difficulties it posed for reaching "true basement." All shipboard support by the technical staff is gratefully acknowledged, together with shore-based analysts at Keele, Bedford New College, Risley Research Reactor (in the U.K.), Washington (U.S.A.), and Vandoeuvre (France). We also acknowledge the helpful comments of Drs. R. Batiza and M. Storey.

\section{REFERENCES}

Basaltic Volcanism Study Project, 1981. Basaltic Volcanism on the Terrestrial Planets: New York (Pergamon Press).

Bass, M. N., Moberly, R. M., Rhodes, J. M., Shih, C., and Church, S. E., 1973. Volcanic rocks cored in the Central Pacific, Leg 17, Deep Sea Drilling Project. In Winterer, E. L., Ewing, J. I., et al., Init. Repts. DSDP, 17: Washington (U.S. Govt. Printing Office), 429-503.

Batiza, R., Larson, R. L., Schlanger, S. O., Shcheka, S. A., and Tokuyama, H., 1980. Trace element abundances in basalts of the Nauru Basin. Nature, 286:476-478.

Batiza, R., and Vanko, D. A., 1985. Petrologic evolution of large failed rifts in the East Pacific: petrology of volcanic and plutonic rocks from the Mathematician Ridge area and the Guadalupe Trough. J. Petrol., 26:564-602.

Blanchard, D. P., Rhodes, J. M., Dungan, M. A., Rodgers, K. V., Donaldson, C. H., Brannon, J. C., Jocobs, J. W., and Gibson, E. K., 1976. The chemistry and petrology of basalts from Leg 37 of the Deep Sea Drilling Project. J. Geophys. Res., 81:4231-4246.

Bougault, H., Cambon, P., Corre, M., Joron, J. L., and Treuil, M., 1979. Evidence for variability of magmatic processes and upper mantle heterogeneity in the axial region of the Mid-Atlantic Ridge near $22^{\circ} \mathrm{N}$ and $36^{\circ} \mathrm{N}$. Tectonophysics, 55:11-34.

Bougault, H., Joron, J. L., and Treuil, M., 1980. The primordial chondritic nature and large-scale heterogeneitites in the mantle: evidence from high and low partition coefficient elements in ocean basalts. Philos. Trans. $R$. Soc. London, 297:203-213.

Castillo, P. R., Carlson, R. W., and Batiza, R., 1991. Origin of Nauru Basin igneous complex: $\mathrm{Sr}, \mathrm{Nd}$ and $\mathrm{Pb}$ isotope and REE constraints. Earth Planet. Sci. Lett., 103:200-213. 
Chaffey, D. J., Cliff, R. A., and Wilson, B. M., 1989. Characterization of the St. Helena magma source. In Saunders, A. D., and Norry, M. J. (Eds.), Magmatism in the Ocean Basins. Geol. Soc. Spec. Publ. London, 42:257-276.

Curray, J. R., Moore, D. G., et al., 1982. Init. Repts. DSDP, 64: Washington (U.S. Govt. Printing Office).

Devey, C. W., Albarede, F., Cheminee, J. L., Michard, A., Muhe, R., and Stoffers, P., 1990. Active submarine volcanism on the Society hotspot swell (West Pacific): a geochemical study. J. Geophys. Res., 95:5049-5066.

Einsale, G., Gieskes, J. M., Curray, J., Moore, D. M., Aguago, E., Aubry, M. P., Fornari, D., Guerrero, J., Kastner, M., Kelts, K., Lyle, M., Matoba, Y., Molina-Cruz, A., Niemitz, J., Rueda, J., Saunders, A., Schrader, H., Simoneit, B., and Vacquier, V., 1980. Intrusion of basaltic sills into highly porous sediments and resulting hydrothermal activity. Nature, 283:441-445.

Floyd, P. A., 1986. Petrology and geochemistry of oceanic intraplate sheetflow basalts, Nauru Basin, Deep Sea Drilling Project, Leg 89. In Moberly, R., Schlanger, S. O., et al., Init. Repts. DSDP, 89: Washington (U.S. Govt. Printing Office), 471-497.

1989. Geochemical features of intraplate oceanic plateau basalts. In Saunders, A. D., and Norry, M. J. (Eds.), Magmatism in the Ocean Basins. Geol. Soc. Spec. Publ. London, 42:215-230.

Griffin, B. J., Neuser, R. D., and Schmincke, H.-U., 1983. Lithology, petrography and mineralogy of basalts from DSDP Sites 482, 483, 484 and 485 at the north of the Gulf of California. In Lewis, B.T.R., Robinson, P., et al., Init. Repts. DSDP, 65: Washington (U.S. Govt. Printing Office), 527-548.

Haggerty, J. A., Schlanger, S. O., and Premoli-Silva, I., 1982. Late Cretaceous and Eocene volcanism in the southern Line Islands and implications for hotspot theory. Geology, 10:433-437.

Harland, W. B., Cox, A. V., Llewellyn, P. G., Pickton, C.A.G., Smith, D. G., and Walters, R., 1982. A Geologic Time Scale: Cambridge (Cambridge Univ. Press).

Houghton, R. L., 1979. Petrology and geochemistry of basaltic rocks recovered on Leg 43 on the Deep Sea Drilling Project. In Tucholke, B. E., Vogt, P. R., et al., Init. Repts. DSDP, 43: Washington (U.S. Govt. Printing Office), $721-738$.

Humphris, S. E., and Thompson, G., 1978. Hydrothermal alteration of oceanic basalts by seawater. Geochim. Cosmochim. Acta, 42:107-126.

Joron, J. L., and Treuil, M., 1989. Hygromagmaphile element distributions in ocean basalts as fingerprints of partial melting and mantle heterogeneities: a specific approach and proposal of an identification and modelling method. In Saunders, A. D., and Norry, M. J. (Eds.), Magmatism in the Ocean Basins. Geol. Soc. Spec. Publ. London, 42:277-299.

Klein, G. deV., Kobayashi, K., et al., 1980. Init. Repts. DSDP, 58: Washington (U.S. Govt. Printing Office).

Lancelot, Y., Larson, R. L., et al., 1990. Proc. ODP, Sci. Results, 129: College Station, TX (Ocean Drilling Program).

Larson, R. L., 1991. Latest pulse of Earth: evidence for a mid-Cretaceous superplume. Geology, 19:547-550.

Larson, R. L., and Schlanger, S. O., 1981. Geological evolution of the Nauru Basin and regional implications. In Larson, R. L., Schlanger, S. O., et al., Init. Repts. DSDP, 61: Washington (U.S. Govt. Printing Office), 841-862.

Larson, R. L., Schlanger, S. O., et al., 1981. Init. Repts. DSDP, 61: Washington (U.S. Govt. Printing Office).

Leinen, M., Rea, D. K., et al., 1986. Init. Repts. DSDP, 92: Washington (U.S. Govt. Printing Office).

Lipman, P. W., Clague, D. A., Moore, J. G., and Holcomb, R. T., 1989. South Arch volcanic field-newly identified young lava flows on the seafloor south of the Hawaiian Ridge. Geology, 17:611-614.

Mahoney, J. J., 1987. An isotopic survey of Pacific oceanic plateaus: implications for their nature and origin. In Keating, B. H., Fryer, P., Batiza, R., and Boehlert, G. W. (Eds.), Seamounts, Islands and Atolls. Am. Geophys. Union, Geophys. Monogr., 43:207-220.

Mahoney, J. J., and Spencer, K. J., 1991. Isotopic evidence for the origin of the Manihiki and Ontong-Java oceanic plateaus. Earth Planet. Sci. Lett., 104:196-210.
Marsh, N. G., Saunders, A. D., Tarney, J., and Dick, H.J.B., 1980. Geochemistry of basalts from the Shikoku and Daito Basins, Deep Sea Drilling Project Leg 58. In Klein, G. deV., Kobayashi, K., et al., Init. Repts. DSDP, 58: Washington (U.S. Govt. Printing Office), 805-842.

Mattey, D. P., 1982. The minor and trace element geochemistry of volcanic rocks from Truk, Ponape and Kusaie, Eastern Caroline Islands: the evolution of a young hot spot trace across old Pacific Ocean crust. Contrib. Mineral. Petrol., 80:1-13.

Meschede, M., 1986. A method of discriminating between different types of mid-ocean ridge basalts and continental tholeiities with the $\mathrm{Nb}-\mathrm{Zr}-\mathrm{Y}$ diagram. Chem. Geol., 56:207-218.

Moberly, R., Schlanger, S. O., et al., 1986. Init. Repts. DSDP, 89: Washington (U.S. Govt. Printing Ofice).

Pearce, J. A., and Norry, M. J., 1979. Petrogenetic implications of Ti, Zr, Y and $\mathrm{Nb}$ variations in volcanic rocks. Contrib. Mineral. Petrol., 69:33-47.

Pearce, J. A., Rogers, N., Tindle, A. J., and Watson, J. S., 1986. Geochemistry and petrogenesis of basalts from Deep Sea Drilling Project Leg 92, Eastern Pacific. In Leinen, M., Rea, D. K., et al., Init. Repts. DSDP, 92: Washington (U.S. Govt. Printing Office), 435-457.

Rea, D. K., and Vallier, T. L., 1983. Two Cretaceous volcanic episodes in the western Pacific Ocean. Bull. Geol. Soc. Am., 94:1430-1437.

Richards, M. A., Duncan, R. A., and Courtillot, V. E., 1989. Flood basalts and hot-spot tracks: plume heads and tails. Science, 246:103-107.

Saunders, A. D., 1984. The rare earth element characteristics of igneous rocks from the ocean basins. In Henderson, P. (Ed.), Rare Earth Element Geochemistry: Amsterdam (Elsevier), 205-236.

1986. Geochemistry of basalts from the Nauru Basin Deep Sea Drilling Project Legs 61 and 89: implications for the origin of oceanic flood basalts. In Moberly, R., Schlanger, S. O., et al., Init. Repts. DSDP, 89: Washington (U.S. Govt. Printing Office), 499-517.

Saunders, A. D., Fornari, D. J., Joron, J. L., Tarney, J., and Treuil, M., 1982. Geochemistry of basic igneous rocks, Gulf of California, Deep Sea Drilling Project Leg 64. In Curray, J. R., Moore, D. G., et al., Init. Repts. DSDP, 64: Washington (U.S. Govt. Printing Office), 595-642.

Schlanger, S. O., Jenkyns, H., and Premoli-Silva, I., 1981. Volcanism and vertical tectonics in the Pacific basin related to global Cretaceous transgressions. Earth Planet. Sci. Lett., 52:435-449.

Schlanger, S. O., and Moberly, R., 1986. Sedimentary and volcanic history: East Mariana Basin and Nauru Basin. In Moberly, R., Schlanger, S. O. et al., Init. Repts. DSDP, 89: Washington (U.S. Govt. Printing Office), 653-678.

Staudigel, H., and Schmincke, H.-U., 1984. The Pliocene seamount series of La Palma/Canary Islands. J. Geophys. Res., 89:11195-11215.

Sun, S. S., and McDonough, W. F., 1989. Chemical and isotopic systematics of ocean basalts: implications for mantle composition and processes. In Saunders, A. D., and Norry, M. J. (Eds.), Magmatism in the Ocean Basins. Geol. Soc. Spec. Publ. London, 42:313-345.

Tucholke, B. E., Vogt, P. R., et al., 1979. Init. Repts. DSDP, 43: Washington (U.S. Govt. Printing Office).

White, W. M., Tapia, M.D.M., and Schilling, J.-G., 1979. The petrology and geochemistry of the Azores Islands. Contrib. Mineral. Petrol., 69:201-213.

Winterer, E. L., 1973. Regional problems. In Winterer, E. L., Ewing, J. I., et al., Init. Repts. DSDP, 17: Washington (U.S. Govt. Printing Office), 911-922.

Winterer, E. L., Ewing, J. I., et al., Init. Repts. DSDP, 17: Washington (U.S. Govt. Printing Office).

Wood, D. A., 1980. The application of a Th-Hf-Ta diagram to problems of tectonomagmatic classification and to establishing the nature of crustal contamination of basaltic lavas of the British Tertiary Volcanic Province. Earth Planet. Sci. Lett., 50:11-30.

Date of initial receipt: 23 May 1991

Date of acceptance: 27 January 1992

Ms 129B-128 


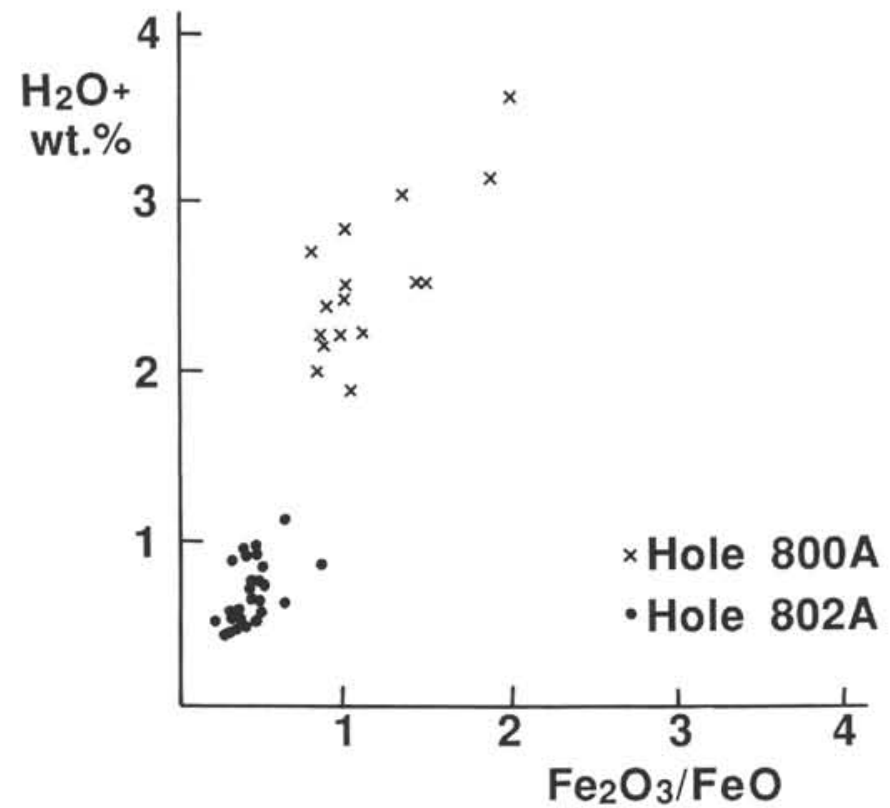

Figure 4. Alteration parameters for Holes $800 \mathrm{~A}$ and $802 \mathrm{~A}$ basic rocks. Apart from sections of the $800 \mathrm{~A}$ dolerite sills, oxidation is low. 
P. A. FLOYD, J. A. WINCHESTER, P. R. CASTILLO

Table 2. Major oxide and trace element data for Hole 802A tholeiitic basalt lavas.

\begin{tabular}{|c|c|c|c|c|c|c|c|c|c|c|c|c|}
\hline Core, section & 57R-2 & $57 R-3$ & 57R-3 & $58 \mathrm{R}-1$ & $58 \mathrm{R}-2$ & $58 \mathrm{R}-2$ & $58 \mathrm{R}-2$ & 58R-2 & $58 \mathrm{R}-2$ & $58 \mathrm{R}-3$ & 58R-3 & $58 \mathrm{R}-3$ \\
\hline Interval $(\mathrm{cm})$ & $109-115$ & $1-6$ & $37-42$ & $9-13$ & $96-100$ & $18-23$ & $91-96$ & $99-102$ & $117-122$ & $23-28$ & $90-95$ & $134-140$ \\
\hline Depth (mbsf) & 509.19 & 509.61 & 509.97 & 516.09 & 516.96 & 517.68 & 518.41 & 518.49 & 518.67 & 519.23 & 519.90 & 520.34 \\
\hline Cooling unit & Al & Al & Al & $\mathrm{A} 2$ & $\mathrm{~A} 2$ & $\mathrm{~A} 2$ & $\mathrm{~A} 2$ & A3 & A4 & A5 & A5 & A. 5 \\
\hline \multicolumn{13}{|c|}{ Major oxides (wt\%) } \\
\hline $\mathrm{SiO}_{2}$ & 48.66 & 49.50 & 49.96 & 50.56 & 49.55 & 50.76 & 49.18 & 49.40 & 49.36 & 50.46 & 49.34 & 50.66 \\
\hline $\mathrm{TiO}_{2}$ & 1.42 & 1.17 & 1.18 & 1.13 & 1.09 & 1.11 & 1.19 & 1.22 & 1.15 & 1.22 & 1.10 & 1.14 \\
\hline $\mathrm{Al}_{2} \overline{\mathrm{O}}_{3}$ & 16.53 & 14.80 & 14.50 & 14.45 & 14.21 & 14.20 & 14.27 & 14.39 & 14.38 & 14.78 & 14.25 & 14.35 \\
\hline $\mathrm{Fe}_{2} \mathrm{O}_{3}$ & 5.91 & 4.10 & 3.56 & 3.75 & 3.07 & 3.31 & 3.46 & 2.54 & 3.75 & 3.69 & 4.40 & 3.43 \\
\hline $\mathrm{FeO}$ & 4.75 & 6.43 & 7.26 & 7.33 & 8.58 & 8.29 & 8.02 & 8.83 & 8.17 & 6.36 & 7.56 & 7.28 \\
\hline $\mathrm{MnO}$ & 0.16 & 0.20 & 0.21 & 0.19 & 0.21 & 0.18 & 0.20 & 0.21 & 0.21 & 0.16 & 0.20 & 0.17 \\
\hline $\mathrm{MgO}$ & 7.42 & 7.87 & 7.79 & 7.68 & 8.05 & 7.50 & 7.69 & 7.66 & 7.68 & 7.34 & 7.71 & 8.03 \\
\hline $\mathrm{CaO}$ & 8.53 & 11.70 & 11.69 & 11.72 & 11.76 & 11.69 & 11.73 & 11.78 & 11.87 & 11.96 & 11.73 & 11.93 \\
\hline $\mathrm{Na}_{2} \mathrm{O}$ & 2.78 & 2.65 & 2.57 & 2.10 & 2.00 & 2.01 & 2.10 & 1.95 & 1.95 & 2.33 & 2.04 & 1.99 \\
\hline $\mathrm{K}_{2} \mathrm{O}$ & 0.84 & 0.10 & 0.09 & 0.08 & 0.07 & 0.10 & 0.24 & 0.18 & 0.14 & 0.08 & 0.25 & 0.03 \\
\hline $\mathrm{P}_{2} \mathrm{O}_{5}$ & 0.10 & 0.04 & 0.03 & 0.03 & 0.03 & 0.03 & 0.03 & 0.02 & 0.03 & 0.02 & 0.02 & 0.10 \\
\hline LOI & 2.70 & 1.17 & 1.02 & 1.00 & 0.98 & 0.97 & 1.00 & 0.86 & 1.08 & 1.50 & 1.09 & 0.90 \\
\hline Total & 99.79 & 99.73 & 99.86 & 100.091 & 99.61 & 100.13 & 99.11 & 99.03 & 99.77 & 99.90 & 99.69 & 100.10 \\
\hline $\mathrm{H}_{2} \mathrm{O}+$ & 2.05 & 1.11 & 0.63 & 0.57 & 0.54 & 0.44 & 0.64 & 0.54 & 0.90 & 0.65 & 0.65 & 0.51 \\
\hline $\mathrm{CO}_{2}$ & 0.58 & 0.12 & 0.22 & 0.18 & 0.10 & 0.10 & 0.16 & 0.11 & 0.13 & 0.62 & 0.15 & 0.06 \\
\hline \multicolumn{13}{|c|}{ Trace elements by XRF (ppm) } \\
\hline $\mathrm{Ba}$ & 56 & 10 & 26 & 9 & 16 & 32 & 11 & 20 & 14 & 18 & 12 & 28 \\
\hline $\mathrm{Ce}$ & 17 & 12 & 10 & 8 & 25 & 12 & 26 & 10 & 7 & 7 & 8 & 3 \\
\hline $\mathrm{Cr}$ & 167 & 156 & 138 & 125 & 150 & 131 & 151 & 155 & 159 & 134 & 141 & 136 \\
\hline $\mathrm{Cu}$ & 162 & 157 & 155 & 153 & 153 & 159 & 148 & 157 & 150 & 156 & 144 & 161 \\
\hline Ga & 20 & 15 & 17 & 16 & 17 & 21 & 16 & 15 & 16 & 16 & 19 & 16 \\
\hline La & 3 & 2 & 3 & 2 & 5 & 4 & 2 & 4 & 2 & 2 & 2 & 2 \\
\hline $\mathrm{Nb}$ & 7 & 4 & 4 & 3 & 4 & 4 & 4 & 4 & 4 & 4 & 4 & 5 \\
\hline $\mathrm{Nd}$ & 7 & 4 & 5 & 16 & 23 & 13 & 25 & 10 & 8 & 6 & 10 & 5 \\
\hline $\mathrm{Ni}$ & 88 & 103 & 100 & 96 & 98 & 95 & 96 & 99 & 101 & 100 & 99 & 99 \\
\hline $\mathrm{Pb}$ & 4 & 5 & 6 & 6 & 6 & 6 & 6 & 4 & 5 & 4 & 6 & 2 \\
\hline $\mathrm{Rb}$ & 8 & 4 & 2 & 1 & 2 & 1 & 6 & 2 & 4 & 1 & 8 & 1 \\
\hline S & 234 & 400 & 275 & 189 & 252 & 302 & 279 & 284 & 322 & 217 & 272 & 242 \\
\hline $\mathrm{Sr}$ & 161 & 98 & 104 & 102 & 99 & 97 & 98 & 95 & 94 & 106 & 99 & 99 \\
\hline V & 423 & 357 & 354 & 359 & 332 & 342 & 346 & 358 & 355 & 349 & 351 & 363 \\
\hline $\mathrm{Y}$ & 28 & 25 & 24 & 25 & 24 & 25 & 26 & 25 & 25 & 25 & 24 & 24 \\
\hline $\mathrm{Zn}$ & 119 & 92 & 90 & 91 & 95 & 91 & 94 & 97 & 94 & 93 & 92 & 94 \\
\hline $\mathrm{Zr}$ & 101 & 64 & 67 & 66 & 65 & 64 & 65 & 65 & 65 & 65 & 63 & 63 \\
\hline \multicolumn{13}{|c|}{ Trace element INAA (ppm) } \\
\hline Cs & 0.09 & - & 0.20 & 0.10 & - & 0.10 & - & - & 0.15 & 0.045 & 0.19 & - \\
\hline $\mathrm{Hf}$ & 2.30 & - & 1.76 & 1.90 & - & 1.60 & - & - & 1.76 & 1.80 & 1.64 & - \\
\hline $\mathrm{Sc}$ & 48.8 & - & 49.4 & 46.5 & - & 47.8 & - & - & 49.0 & 48.6 & 47.7 & - \\
\hline $\mathrm{Ta}$ & 0.46 & - & 0.19 & 0.186 & - & 0.165 & - & - & 0.17 & 0.16 & 0.165 & - \\
\hline Th & 0.62 & - & 0.22 & 0.28 & - & 0.26 & - & - & 0.25 & 0.26 & 0.18 & - \\
\hline $\mathrm{U}$ & 0.17 & - & 0.40 & 0.076 & - & 0.09 & - & - & 0.50 & 0.097 & 0.50 & - \\
\hline \multicolumn{13}{|c|}{ Rare earth elements (ppm) } \\
\hline La & 9.07 & - & 3.17 & 3.93 & - & 3.83 & - & - & 3.08 & 4.08 & 3.00 & - \\
\hline $\mathrm{Ce}$ & 19.88 & - & 8.60 & 9.93 & - & 10.02 & - & - & 8.50 & 10.31 & 8.00 & - \\
\hline $\mathrm{Pr}$ & 2.65 & - & - & 1.46 & - & 1.46 & - & - & - & 1.51 & - & - \\
\hline $\mathrm{Nd}$ & 12.73 & - & 15.00 & 7.94 & - & 7.76 & - & - & 6.20 & 8.21 & 6.00 & - \\
\hline $\mathrm{Sm}$ & 3.19 & - & 2.32 & 2.25 & - & 2.23 & - & - & 2.22 & 2.38 & 2.25 & - \\
\hline $\mathrm{Eu}$ & 1.22 & - & 0.88 & 0.89 & - & 0.87 & - & - & 0.87 & 0.91 & 0.814 & - \\
\hline Gd & 4.16 & - & - & 3.34 & - & 3.28 & - & - & - & 3.50 & - & - \\
\hline $\mathrm{Tb}$ & - & - & 0.57 & - & - & - & - & - & 0.56 & - & 0.54 & - \\
\hline Dy & 4.61 & - & - & 4.08 & - & 4.08 & - & - & - & 4.17 & - & - \\
\hline Ho & 0.87 & - & - & 0.82 & - & 0.83 & - & - & - & 0.83 & - & - \\
\hline $\mathrm{Er}$ & 2.52 & - & - & 2.47 & - & 2.44 & - & - & - & 2.48 & - & - \\
\hline $\mathrm{Yb}$ & 2.36 & - & 2.37 & 2.49 & - & 2.38 & - & - & 2.41 & 2.51 & 2.28 & - \\
\hline $\mathrm{Lu}$ & 0.39 & - & 0.356 & 0.43 & - & 0.41 & - & - & 0.36 & 0.43 & 0.357 & - \\
\hline
\end{tabular}

Note: Dash ( $\longrightarrow$ ) indicates element not determined. 
Table 2 (continued).

\begin{tabular}{|c|c|c|c|c|c|c|c|c|c|c|c|c|c|}
\hline $58 \mathrm{R}-4$ & $58 \mathrm{R}-4$ & $59 \mathrm{R}-1$ & $59 \mathrm{R}-1$ & $59 \mathrm{R}-1$ & $59 \mathrm{R}-1$ & $59 \mathrm{R}-1$ & $59 \mathrm{R}-2$ & $59 \mathrm{R}-2$ & 59R-2 & 59R-2 & $59 \mathrm{R}-3$ & $59 \mathrm{R}-3$ & 59R-3 \\
\hline $24-29$ & $65-70$ & $7-12$ & $70-75$ & $78-82$ & $130-136$ & $138-142$ & $8-13$ & $15-19$ & $100-105$ & $123-127$ & $17-22$ & $40-44$ & $127-132$ \\
\hline 520.74 & 521.15 & 525.47 & 526.10 & 526.18 & 526.70 & 526.78 & 526.98 & 527.05 & 527.90 & 528.13 & 528.49 & 528.72 & 529.59 \\
\hline A5 & A5 & A7 & A8 & A8 & A9 & A9 & A9 & A9 & A 10 & All & $\mathrm{A} 12$ & $\mathrm{~A} 13$ & $\mathrm{~A} 13$ \\
\hline 50.64 & 49.32 & 49.46 & 49.59 & 49.76 & 49.76 & 49.27 & 49.95 & 49.58 & 49.52 & 49.38 & 50.48 & 49.98 & 50.34 \\
\hline 1.17 & 1.12 & 1.21 & 1.22 & 1.14 & 1.10 & 1.10 & 1.24 & 1.11 & 1.21 & 1.10 & 1.16 & 1.23 & 1.20 \\
\hline 14.10 & 14.55 & 14.72 & 14.23 & 14.09 & 14.26 & 14.43 & 14.29 & 14.31 & 14.42 & 14.37 & 14.59 & 14.27 & 14.24 \\
\hline 3.01 & 3.87 & 3.60 & 2.41 & 2.73 & 3.55 & 3.99 & 2.97 & 3.30 & 2.60 & 3.65 & 3.18 & 2.03 & 2.65 \\
\hline 8.35 & 8.23 & 7.63 & 8.57 & 8.63 & 8.52 & 7.88 & 8.29 & 8.83 & 8.34 & 8.47 & 7.83 & 9.17 & 8.35 \\
\hline 0.17 & 0.21 & 0.19 & 0.20 & 0.20 & 0.21 & 0.21 & 0.19 & 0.21 & 0.20 & 0.21 & 0.18 & 0.21 & 0.21 \\
\hline 7.56 & 7.57 & 7.98 & 7.94 & 7.92 & 7.66 & 7.64 & 7.68 & 7.71 & 8.07 & 7.67 & 7.51 & 7.67 & 7.72 \\
\hline 11.65 & 11.96 & 11.97 & 12.13 & 12.02 & 11.85 & 11.58 & 11.85 & 12.02 & 12.12 & 11.85 & 11.84 & 11.85 & 11.78 \\
\hline 2.06 & 2.04 & 2.08 & 1.96 & 1.91 & 1.92 & 2.07 & 2.00 & 1.92 & 2.01 & 1.95 & 2.13 & 2.00 & 1.97 \\
\hline 0.08 & 0.13 & 0.08 & 0.06 & 0.08 & 0.14 & 0.18 & 0.20 & 0.14 & 0.05 & 0.13 & 0.11 & 0.10 & 0.08 \\
\hline 0.02 & 0.03 & 0.03 & 0.10 & 0.03 & 0.02 & 0.02 & 0.09 & 0.02 & 0.02 & 0.02 & 0.02 & 0.02 & 0.02 \\
\hline 0.95 & 1.05 & 0.98 & 1.11 & 1.04 & 1.03 & 1.09 & 1.05 & 0.90 & 0.99 & 0.91 & 0.87 & 0.84 & 1.08 \\
\hline 99.76 & 100.06 & 99.93 & 99.56 & 99.53 & 100.02 & 99.45 & 99.80 & 100.06 & 99.56 & 99.72 & 99.91 & 99.37 & 99.64 \\
\hline 0.46 & 0.94 & 0.64 & 0.43 & 0.53 & 0.92 & 0.73 & 0.58 & 0.54 & 0.50 & 0.71 & 0.51 & 0.50 & 0.86 \\
\hline 0.10 & 0.08 & 0.13 & 0.26 & 0.18 & 0.07 & 0.24 & 0.13 & 0.13 & 0.27 & 0.07 & 0.24 & 0.18 & 0.10 \\
\hline 13 & 22 & 7 & 19 & 34 & 22 & 14 & 23 & 17 & 9 & 16 & 17 & 32 & 29 \\
\hline 10 & 10 & 8 & 4 & 11 & 4 & 5 & 6 & 6 & 7 & 5 & 8 & 8 & 10 \\
\hline 136 & 180 & 139 & 131 & 144 & 166 & 148 & 138 & 155 & 133 & 165 & 134 & 150 & 145 \\
\hline 154 & 156 & 163 & 164 & 155 & 152 & 152 & 157 & 151 & 157 & 151 & 151 & 150 & 156 \\
\hline 18 & 17 & 15 & 15 & 14 & 18 & 17 & 16 & 17 & 17 & 18 & 17 & 18 & 16 \\
\hline 2 & 3 & 1 & 3 & 4 & 4 & 3 & 3 & 3 & 1 & 1 & 2 & 2 & 2 \\
\hline 3 & 4 & 3 & 5 & 3 & 4 & 3 & 5 & 4 & 4 & 5 & 4 & 4 & 3 \\
\hline 4 & 5 & 9 & 8 & 7 & 12 & 10 & 8 & 12 & 15 & 4 & 7 & 10 & 20 \\
\hline 93 & 110 & 103 & 96 & 93 & 105 & 100 & 100 & 100 & 98 & 105 & 98 & 100 & 102 \\
\hline 7 & 4 & 4 & 1 & 4 & 4 & 5 & 4 & 6 & 6 & 5 & 6 & 4 & 6 \\
\hline 1 & 1 & 1 & $i$ & 1 & 1 & 4 & 4 & 4 & 1 & 2 & 2 & 2 & 2 \\
\hline 315 & 330 & 293 & 244 & 249 & 245 & 255 & 249 & 263 & 246 & 259 & 407 & 266 & 264 \\
\hline 96 & 95 & 100 & 97 & 98 & 93 & 100 & 96 & 96 & 99 & 96 & 100 & 95 & 95 \\
\hline 340 & 367 & 373 & 336 & 344 & 345 & 350 & 349 & 338 & 340 & 349 & 346 & 348 & 346 \\
\hline 25 & 25 & 25 & 25 & 25 & 25 & 25 & 25 & 25 & 25 & 25 & 26 & 25 & 25 \\
\hline 90 & 97 & 97 & 93 & 88 & 96 & 100 & 94 & 95 & 90 & 97 & 92 & 95 & 93 \\
\hline 63 & 65 & 66 & 64 & 65 & 64 & 65 & 64 & 65 & 64 & 64 & 64 & 63 & 63 \\
\hline- & 0.30 & 0.10 & - & - & 0.08 & - & - & - & 0.10 & 0.16 & - & - & 0.20 \\
\hline- & 1.83 & 1.50 & - & - & 1.65 & - & - & - & 1.60 & 1.69 & - & - & 1.76 \\
\hline- & 49.0 & 47.6 & - & - & 48.1 & - & - & - & 47.6 & 48.9 & - & - & 48.5 \\
\hline- & 0.17 & 0.17 & - & - & 0.177 & - & - & - & 0.168 & 0.19 & - & - & 0.17 \\
\hline- & 0.23 & 0.24 & - & - & 0.22 & - & - & - & 0.26 & 0.20 & - & - & 0.20 \\
\hline- & 0.30 & 0.112 & - & - & 0.30 & - & - & - & 0.074 & 0.40 & - & - & 0.30 \\
\hline- & 3.18 & 3.96 & - & - & 3.16 & - & - & - & 4.86 & 3.14 & - & - & 3.13 \\
\hline- & 8.30 & 10.28 & - & - & 8.10 & - & - & - & 10.82 & 8.70 & - & - & 8.30 \\
\hline- & - & 1.47 & - & - & - & - & - & - & 1.51 & - & - & - & - \\
\hline- & 9.00 & 8.30 & - & - & 5.00 & - & - & - & 7.94 & 8.00 & - & - & 17.00 \\
\hline- & - & 2.35 & - & - & 2.35 & - & - & - & 2.20 & 2.31 & - & - & 2.25 \\
\hline- & - & 0.91 & - & - & 0.863 & - & - & - & 0.88 & 0.88 & - & - & 0.86 \\
\hline- & - & 3.34 & - & - & - & - & - & - & 3.15 & - & - & - & - \\
\hline - & 0.57 & - & - & - & 0.567 & - & - & - & - & 0.56 & - & - & 0.60 \\
\hline- & - & 4.32 & - & - & - & - & - & - & 4.05 & - & - & - & - \\
\hline- & - & 0.85 & - & - & - & - & - & - & 0.80 & - & - & - & - \\
\hline- & - & 2.59 & - & - & - & - & - & - & 2.43 & - & - & - & - \\
\hline- & 2.41 & 2.57 & - & - & 2.37 & - & - & - & 2.47 & 2.43 & - & - & 2.36 \\
\hline- & 0.358 & 0.43 & - & - & 0.359 & - & - & - & 0.42 & 0.364 & - & - & 0.372 \\
\hline
\end{tabular}


P. A. FLOYD, J. A. WINCHESTER, P. R. CASTILLO

Table 2 (continued).

\begin{tabular}{|c|c|c|c|c|c|c|c|c|c|c|c|c|}
\hline Core, section & $60 \mathrm{R}-1$ & $60 R-1$ & $6 \mid R-1$ & $61 R-1$ & $61 \mathrm{R}-2$ & $62 \mathrm{R}-1$ & $62 R-1$ & $62 R-2$ & $62 \mathrm{R}-2$ & $62 R-2$ & $62 R-3$ & $62 \mathrm{R}-3$ \\
\hline Interval $(\mathrm{cm})$ & $11-16$ & $78-84$ & $32-37$ & $139-144$ & $14-21$ & $0-7$ & $112-118$ & $30-35$ & $45-50$ & $53-59$ & $12-18$ & $27-33$ \\
\hline Depth (mbsf) & 534.81 & 5.35 .48 & 544.52 & 545.59 & 545.84 & 550.60 & 551.72 & 552.36 & 552.51 & 552.59 & 553.60 & 553.75 \\
\hline Cooling unit & Al4 & Al4 & A15 & A16 & A16 & A17 & A17 & A17 & A17 & A17 & A17 & A17 \\
\hline \multicolumn{13}{|c|}{ Major oxides (wt $\%$ ) } \\
\hline $\mathrm{SiO}_{2}$ & 50.01 & 51.00 & 49.31 & 50.62 & 50.31 & 50.76 & 50.77 & 50.48 & 49.35 & 50.79 & 50.41 & 50.65 \\
\hline $\mathrm{TiO}_{2}$ & 1.11 & 1.20 & 1.19 & 1.09 & 1.22 & 1.17 & 1.06 & 1.12 & 1.28 & 1.09 & 1.08 & 1.08 \\
\hline $\mathrm{Al}_{2} \mathrm{O}_{3}$ & 14.44 & 16.28 & 14.64 & 14.13 & 14.05 & 14.40 & 14.11 & 13.88 & 14.43 & 14.25 & 14.27 & 14.17 \\
\hline $\mathrm{Fe}_{2} \mathrm{O}_{3}$ & 2.85 & 4.15 & 3.71 & 3.28 & 3.19 & 3.41 & 3.39 & 3.08 & 4.53 & 3.10 & 3.78 & 3.31 \\
\hline $\mathrm{FeO}$ & 8.79 & 4.77 & 7.70 & 8.21 & 7.87 & 7.52 & 8.29 & 8.46 & 7.10 & 8.49 & 7.62 & 8.35 \\
\hline $\mathrm{MnO}$ & 0.23 & 0.12 & 0.18 & 0.18 & 0.17 & 0.18 & 0.19 & 0.18 & 0.24 & 0.20 & 0.18 & 0.18 \\
\hline $\mathrm{MgO}$ & 7.89 & 7.16 & 7.56 & 7.73 & 7.84 & 7.78 & 7.79 & 7.85 & 7.87 & 7.76 & 7.61 & 7.64 \\
\hline $\mathrm{CaO}$ & 12.15 & 10.97 & 11.72 & 11.54 & 11.28 & 11.29 & 11.72 & 11.68 & 11.74 & 11.79 & 11.63 & 11.82 \\
\hline $\mathrm{Na}_{2} \mathrm{O}$ & 1.99 & 2.52 & 2.08 & 1.99 & 2.35 & 2.24 & 1.96 & 2.04 & 2.10 & 1.93 & 1.92 & 1.99 \\
\hline $\mathrm{K}_{2} \mathrm{O}$ & 0.04 & 0.08 & 0.25 & 0.09 & 0.10 & 0.09 & 0.08 & 0.08 & 0.17 & 0.07 & 0.07 & 0.06 \\
\hline $\mathrm{P}_{2} \mathrm{O}_{5}$ & 0.02 & 0.04 & 0.03 & 0.02 & 0.03 & 0.03 & 0.02 & 0.09 & 0.03 & 0.02 & 0.02 & 0.02 \\
\hline LOI & 0.89 & 1.27 & 1.10 & 0.95 & 1.14 & 1.07 & 0.84 & 1.08 & 1.41 & 0.83 & 1.18 & 0.94 \\
\hline Total & 100.40 & 99.55 & 99.48 & 99.83 & 99.53 & 99.92 & 100.22 & 100.02 & 100.14 & 100.31 & 99.76 & 100.22 \\
\hline $\mathrm{H}_{2} \mathrm{O}+$ & 0.45 & 0.85 & 0.75 & 0.51 & 0.91 & 0.75 & 0.46 & 0.52 & 0.60 & 0.46 & 0.82 & 0.45 \\
\hline $\mathrm{CO}_{2}$ & 0.18 & 0.26 & 0.13 & 0.12 & 0.09 & 0.11 & 0.09 & 0.04 & 0.78 & 0.12 & 0.10 & 0.20 \\
\hline \multicolumn{13}{|c|}{ Trace elements by XRF ( $\mathrm{ppm})$} \\
\hline $\mathrm{Ba}$ & 20 & 21 & 20 & 25 & 29 & 24 & 37 & 25 & 30 & 33 & 29 & 29 \\
\hline $\mathrm{Ce}$ & 5 & 4 & 4 & 2 & 2 & 1 & 9 & 4 & 5 & 4 & 3 & 4 \\
\hline $\mathrm{Cr}$ & 146 & 159 & 160 & 123 & 140 & 134 & 143 & 127 & 130 & 134 & 147 & 133 \\
\hline $\mathrm{Cu}$ & 151 & 159 & 150 & 153 & 156 & 159 & 151 & 162 & 161 & 157 & 159 & 157 \\
\hline Ga & 16 & 18 & 15 & 17 & 17 & 16 & 17 & 15 & 17 & 18 & 16 & 15 \\
\hline La & 2 & 2 & 2 & 2 & 1 & 3 & 2 & 2 & 2 & 2 & 2 & 2 \\
\hline $\mathrm{Nb}$ & 3 & 4 & 4 & 3 & 3 & 4 & 4 & 4 & 4 & 4 & 3 & 4 \\
\hline $\mathrm{Nd}$ & 4 & 7 & 15 & 15 & 5 & 1 & 10 & 3 & 6 & 16 & 5 & 9 \\
\hline $\mathrm{Ni}$ & 102 & 100 & 95 & 95 & 98 & 96 & 99 & 94 & 96 & 95 & 99 & 94 \\
\hline $\mathrm{Pb}$ & 8 & 11 & 5 & 3 & 2 & 5 & 6 & 2 & 3 & 5 & 3 & 5 \\
\hline$R b$ & 1 & 1 & 6 & 2 & 2 & 2 & 1 & 2 & 4 & 1 & 1 & 1 \\
\hline$S$ & 223 & 239 & 264 & 275 & 294 & 194 & 310 & 339 & 300 & 304 & 348 & 313 \\
\hline $\mathrm{Sr}$ & 96 & 118 & 100 & 98 & 93 & 96 & 95 & 94 & 95 & 98 & 94 & 95 \\
\hline V & 341 & 416 & 361 & 332 & 342 & 356 & 323 & 328 & 340 & 330 & 332 & 329 \\
\hline Y & 24 & 23 & 26 & 24 & 25 & 25 & 25 & 23 & 23 & 24 & 23 & 25 \\
\hline $\mathrm{Zn}$ & 90 & 101 & 101 & 95 & 90 & 91 & 85 & 88 & 90 & 88 & 94 & 92 \\
\hline $\mathrm{Zr}$ & 63 & 70 & 66 & 64 & 64 & 64 & 62 & 62 & 63 & 63 & 62 & 63 \\
\hline \multicolumn{13}{|c|}{ Trace element INAA (ppm) } \\
\hline Cs & 0.17 & 0.20 & 0.16 & - & 0.30 & 0.05 & 0.30 & - & - & 0.10 & 0.20 & - \\
\hline $\mathrm{Hf}$ & 1.68 & 1.95 & 1.70 & - & 1.74 & 1.60 & 1.63 & - & - & 1.60 & 1.73 & - \\
\hline $\mathrm{Sc}$ & 48.2 & 54.3 & 48.7 & - & 48.4 & 50.1 & 48.0 & - & - & 48.6 & 48.2 & - \\
\hline $\mathrm{Ta}$ & 0.18 & 0.19 & 0.18 & - & 0.171 & 0.18 & 0.17 & - & - & 0.186 & 0.18 & - \\
\hline Th & 0.27 & 0.26 & 0.28 & - & 0.25 & 0.24 & 0.19 & - & - & 0.27 & 0.23 & - \\
\hline U & 0.80 & 0.60 & 0.097 & - & 0.40 & 0.076 & 0.70 & - & - & 0.069 & 0.50 & - \\
\hline \multicolumn{13}{|c|}{ Rare earth elements (ppm) } \\
\hline $\mathrm{La}$ & 3.10 & 3.52 & 3.77 & - & 3.28 & 4.21 & 3.02 & - & - & 3.65 & 3.13 & - \\
\hline $\mathrm{Ce}$ & 8.00 & 9.20 & 9.53 & - & 8.30 & 10.17 & 8.10 & - & - & 9.40 & 7.90 & - \\
\hline $\mathrm{Pr}$ & - & - & 1.34 & - & - & 1.54 & - & - & - & 1.50 & - & - \\
\hline $\mathrm{Nd}$ & 7.00 & 19.00 & 7.76 & - & 7.00 & 7.94 & 9.00 & - & - & 7.76 & 8.00 & - \\
\hline $\mathrm{Sm}$ & 2.29 & 2.41 & 2.30 & - & 2.36 & 2.26 & 2.21 & - & - & 2.26 & 2.34 & - \\
\hline Eu & 0.87 & 0.90 & 0.92 & - & 0.90 & 0.89 & 0.85 & - & - & 0.89 & 0.83 & - \\
\hline $\mathrm{Gd}$ & - & - & 3.33 & - & - & 3.37 & - & - & - & 3.24 & - & - \\
\hline $\mathrm{Tb}$ & 0.57 & 0.53 & - & - & 0.57 & - & 0.55 & - & - & - & 0.54 & - \\
\hline Dy & - & - & 4.17 & - & - & 4,08 & - & - & - & 4.11 & - & - \\
\hline Ho & - & - & 0.82 & - & - & 0.83 & - & - & - & 0.82 & - & - \\
\hline Er & - & - & 2.47 & - & - & 2.48 & - & - & - & 2.49 & - & - \\
\hline $\mathrm{Yb}$ & 2.32 & 1.96 & 2.44 & - & 2.48 & 2.46 & 2.30 & - & - & 2.49 & 2.34 & - \\
\hline Lu & 0.369 & 0.281 & 0.41 & - & 0.375 & 0.44 & 0.361 & - & - & 0.42 & 0.367 & - \\
\hline
\end{tabular}



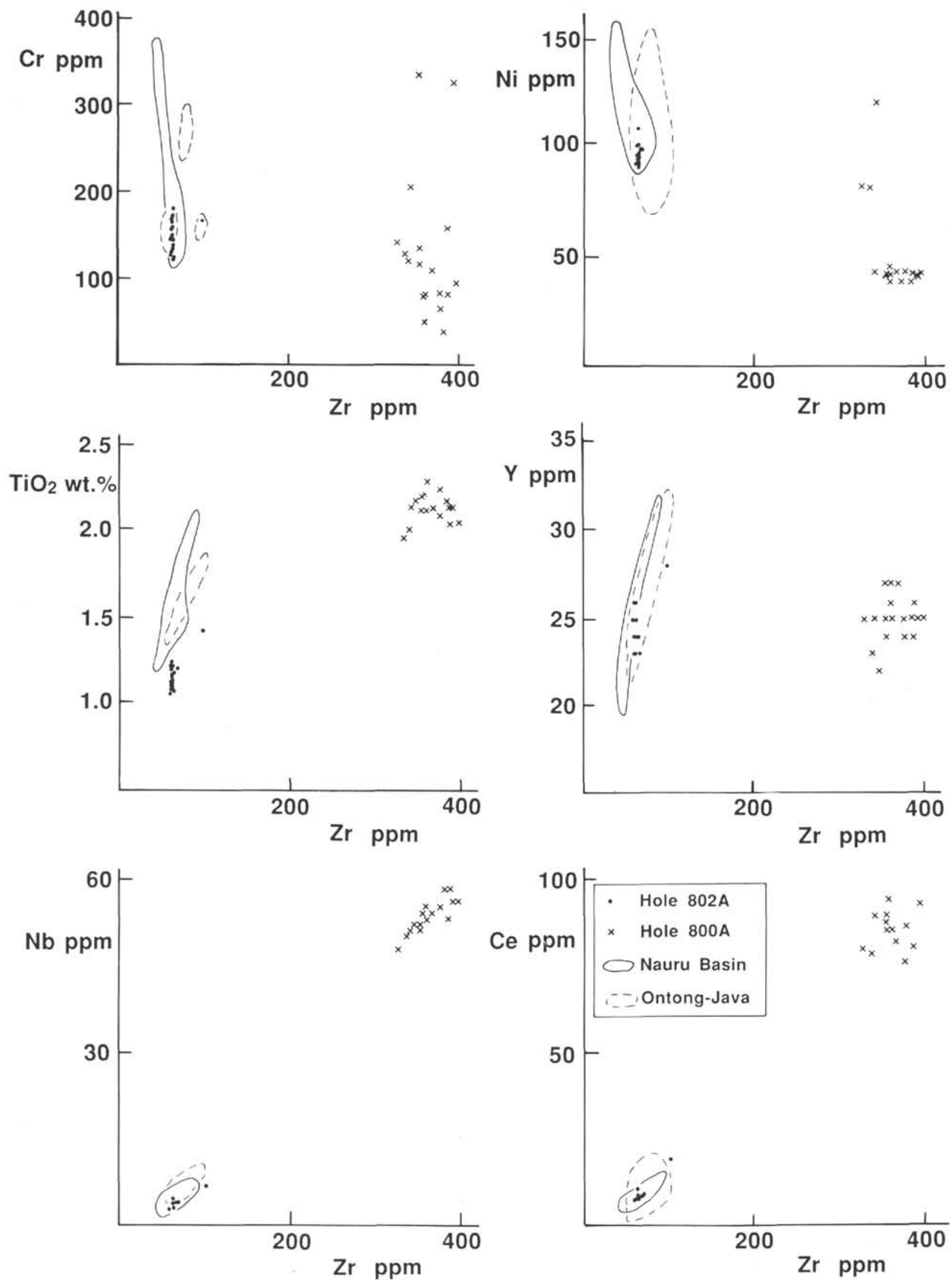

Figure 5. Distribution of $\mathrm{Cr}, \mathrm{Ni}, \mathrm{TiO}_{2}, \mathrm{Y}, \mathrm{Nb}$, and Ce relative to $\mathrm{Zr}$ in Hole $800 \mathrm{~A}$ dolerites and Hole $802 \mathrm{~A}$ tholeiites. Apart from the clear differences in incompatible element contents (excepting Y) between the magma types, note the restricted chemical range illustrated, especially relative to tholeiites from the Nauru Basin (data compiled from Larson, Schlanger, et al., 1981; Moberly, Schlanger, et al., 1986) and Ontong-Java Plateau (Leg 130; M. Storey, pers. comm.). 


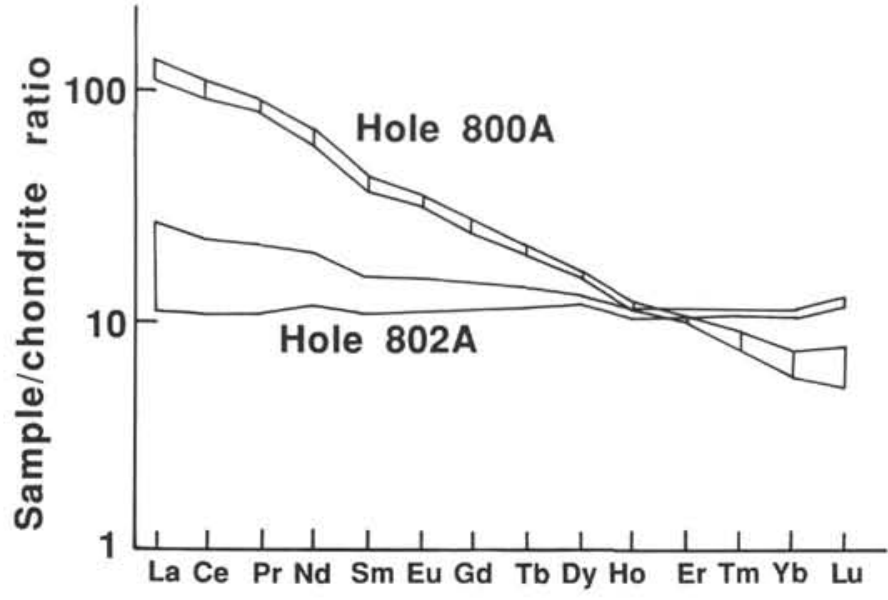

Figure 6. Envelopes incorporating the range of chondrite-normalized REE patterns for Hole 800A alkalic dolerites and Hole 802A tholeiitic flows. Within each group fractionation of the REE is very limited; the tholeiites typically exhibit virtually flat patterns.

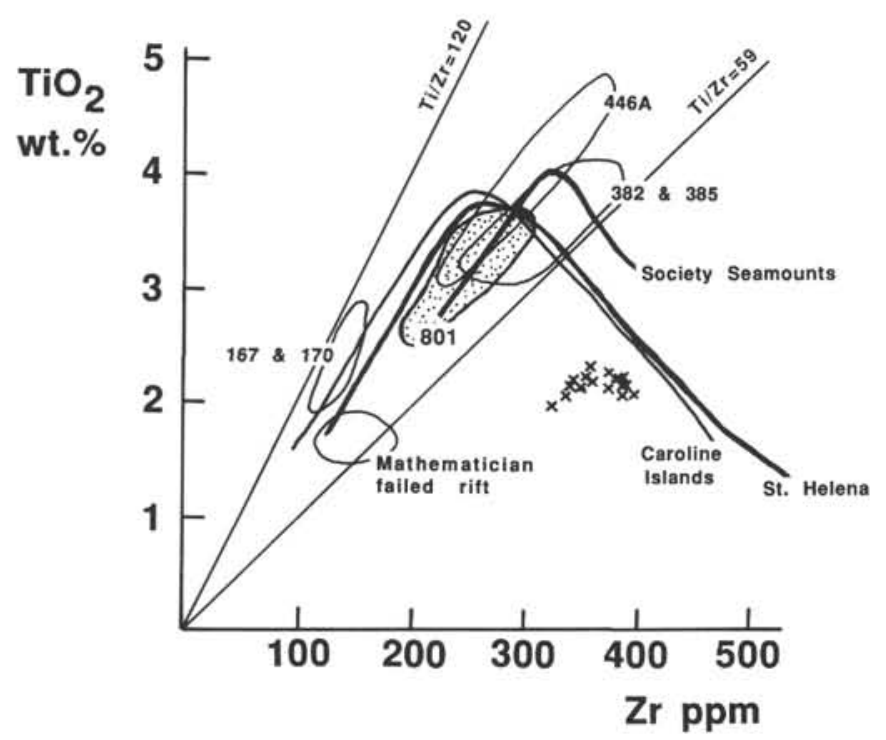

Figure 7. Distribution of $\mathrm{TiO}_{2}$ and $\mathrm{Zr}$ in alkalic basalts from deep-sea submarine sills (envelopes) and oceanic islands (trends) compared with Hole 800A dolerite sills and Leg 129 Site 801 alkalic flows (Floyd and Castillo, this volume). Data sources: Holes 167 and 170 (Bass et al., 1973); Holes 382 and 385 (Houghton, 1979); Holes 446A (Saunders et al., 1982); Mathematician failed rift (Batiza and Vanko, 1985); St. Helena (Chaffey et al., 1989); Caroline Islands (Mattey, 1982) and Society Seamounts (Devey et al., 1990).

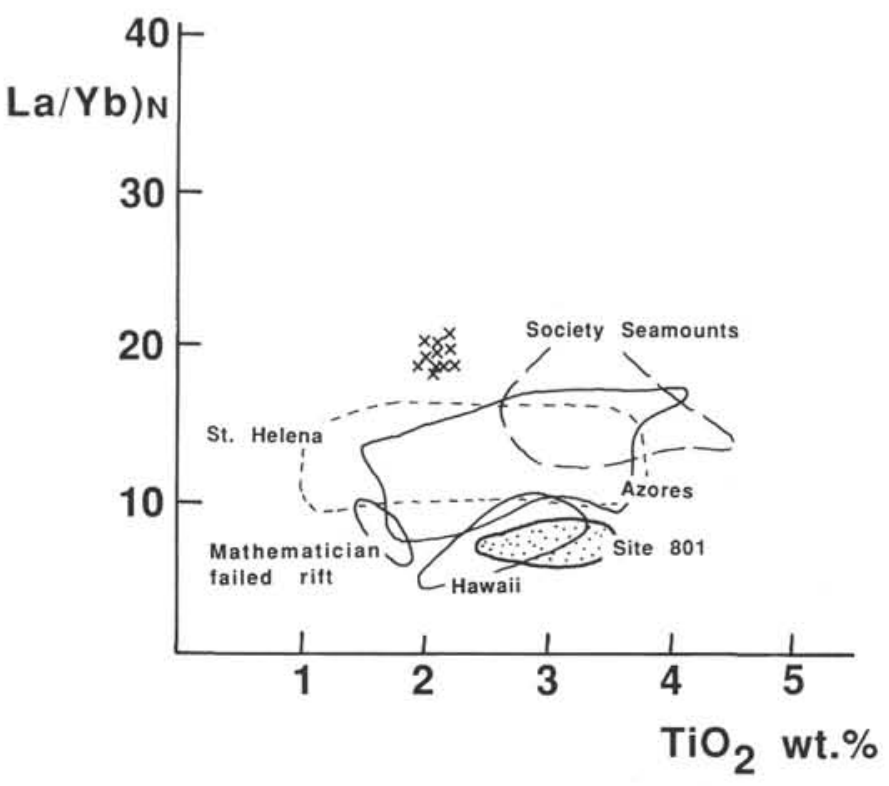

Figure 8. Degree of light REE fractionation (chondrite-normalized $\mathrm{La} / \mathrm{Yb}$ ratio) and $\mathrm{TiO}_{2}$ distributions for various oceanic alkalic basalts relative to Hole $800 \mathrm{~A}$ alkalic dolerites. Note the marked difference between the Leg 129 Site 801 alkalic basalts and the Hole 800A samples. Data sources: Hawaii (Basaltic Volcanism Study Project, 1981); Mathematician failed rift (Batiza and Vanko, 1985); Azores (White et al., 1979); St. Helena (Chaffey et al., 1989); Society Seamounts (Devey et al., 1990).

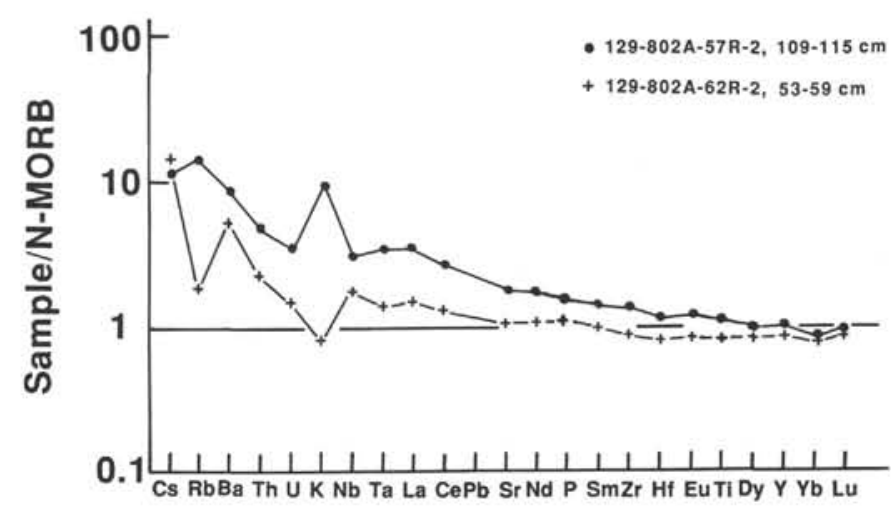

Figure 9. N-MORB normalized multi-element patterns for typical Hole 8002A tholeiite (Sample 129-802A-62R-2, 53-59) and most fractionated variant (Sample 129-802A-57R-2, 109-115). Note the enrichment in LIL elements, together with $\mathrm{Nb}$ and $\mathrm{Ta}$. N-MORB normalization factors from Sun and McDonough (1989). 


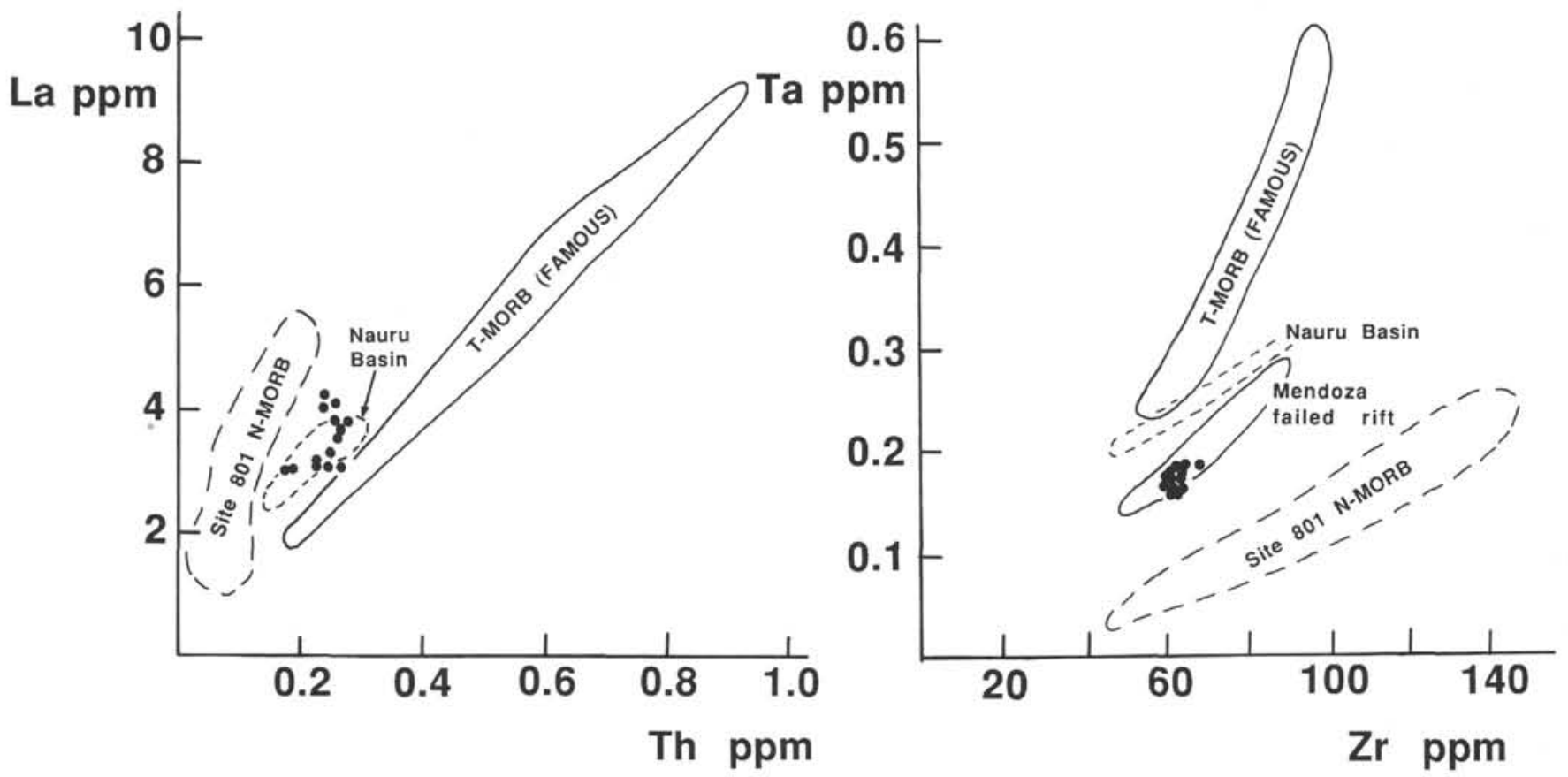

Figure 10. La versus Th and Ta versus $\mathrm{Zr}$ plots showing the distribution of Hole 802A tholeites relative to Jurassic N-MORB (Leg 129, Site 801; Floyd and Castillo, this volume), enriched MORB from the FAMOUS area of the Mid-Atlantic Ridge (Blanchard et al., 1976; Joron and Treuil, 1989), and the Nauru Basin (Saunders, 1984; Floyd, 1986). Mendoza failed rift data from Pearce et al. (1986). 